\title{
The Inventory of Geological Heritage of the State of São Paulo, Brazil: Methodological Basis, Results and Perspectives
}

\author{
Maria da Glória Motta Garcia ${ }^{1}$ - José Brilha ${ }^{2}$ Flávia Fernanda de Lima $^{3,4}$. \\ Jean Carlos Vargas ${ }^{3,4}$ • Annabel Pérez-Aguilar ${ }^{5}$ • Adriana Alves ${ }^{1}$. \\ Ginaldo Ademar da Cruz Campanha ${ }^{1}$ - Wânia Duleba ${ }^{1}$ - Frederico Meira Faleiros ${ }^{1}$. \\ Luiz Alberto Fernandes ${ }^{4}$ - Marisa de Souto Matos Fierz ${ }^{1}$ • Maria Judite Garcia ${ }^{1}$. \\ Valdecir de Assis Janasi ${ }^{1}$ • Lucelene Martins ${ }^{1}$ - Maria Irene Bartolomeu Raposo ${ }^{1}$. \\ Frésia Ricardi-Branco ${ }^{6}$ • Jurandyr Luciano Sanches Ross ${ }^{1}$ - William Sallum Filho ${ }^{5}$. \\ Célia Regina de Gouveia Souza ${ }^{5}$ - Mary Elisabeth C. Bernardes-de-Oliveira ${ }^{1}$. \\ Benjamin Bley de Brito Neves ${ }^{1}$ Mário da Costa Campos Neto ${ }^{1}$. \\ Sérgio Ricardo Christofoletti ${ }^{7}$. Renato Henrique-Pinto ${ }^{1}$ - Heros Augusto Santos Lobo ${ }^{8}$. \\ Rômulo Machado ${ }^{1}$. Cláudia Regina Passarelli ${ }^{1}$. José Alexandre de Jesus Perinotto ${ }^{9}$. \\ Rogério Rodrigues Ribeiro ${ }^{5} \cdot$ Hélio Shimada $^{5}$
}

Received: 18 July 2016 / Accepted: 21 December 2016/Published online: 11 January 2017

(C) The European Association for Conservation of the Geological Heritage 2017

\begin{abstract}
An inventory of geological sites based on solid and clear criteria is a first step for any geoconservation strategy. This paper describes the method used in the geoheritage inventory of the State of São Paulo, Brazil, and presents its main results. This inventory developed by the geoscientific community aimed to identify geosites with scientific value in the whole state, using a systematic approach. All 142 geosites representative of 11 geological frameworks were characterised and quantitatively evaluated according to their scientific value and risk of degradation, in order to establish priorities for their future management. An online database of the inventory is under construction, which will be available to
\end{abstract}

Maria da Glória Motta Garcia

mgmgarcia@usp.br

University of São Paulo, São Paulo, SP, Brazil

University of Minho, Braga, Portugal

Geodiversity Geological Solutions Ltda, Curitiba, PR, Brazil

Federal University of Paraná, Curitiba, PR, Brazil

5 Geological Institute, São Paulo, SP, Brazil

6 State University of Campinas, Campinas, SP, Brazil

7 Forestry Institute, Secretary of State for Environment, São Paulo State, Brazil

8 Federal University of São Carlos, São Carlos, SP, Brazil

9 São Paulo State University, Rio Claro, SP, Brazil be easily consulted and updated by the geoscientific community. All data were made available to the State Geological Institute as the backbone for the implementation of a future state geoconservation strategy.

Keywords Geoheritage $\cdot$ Geosite $\cdot$ Inventory $\cdot$ Brazil

\section{Introduction}

It is generally agreed that any geoconservation strategy must start with an accurate identification of the most valuable elements of geodiversity i.e. an inventory of geological heritage. Globally, the inventory of geological heritage has as one of its basis, the Global Geosites Project, launched in the 1990s by the IUGS Global Geosites Working Group and supported by UNESCO (Wimbledon 1996), with the main objective to produce a comprehensive inventory of geosites according to a systematic methodology. Works associated with this project and carried out in countries such as Portugal (Brilha et al. 2010), Spain (García-Cortéz and Carcavilla Urquí 2009) and other European countries (Wimbledon and Smith-Meyer 2012) show that such data can provide support for the integration of geological information into nature conservation strategies and land use management plans.

These experiences in many countries have led to the improvement of geosite inventory methodologies. According to Lima et al. (2010), the basis for the development of 
inventories in large areas should include (i) good geological knowledge of the whole area; (ii) well-defined objectives and selection criteria; (iii) participation of the geoscientific community and (iv) the involvement of geological institutions.

In Brazil, in part due to the large extent of its territory and to the heterogeneous geological knowledge of it, only recently some initiatives for carrying out geoheritage inventories emerged. At the national level, since 1997, the Brazilian Commission of Geological and Palaeobiological Sites (SIGEP) is assembling a geosite list, currently with about 120 sites, and publishing since 2002 several volumes with description of the geosites. Recently, the Geological Survey of Brazil (CPRM) has developed an online database (GEOSSIT) for inventory, qualification and quantitative evaluation of geological sites at national level, according to the methodology proposed by Brilha (2016) and GarcíaCortéz and Carcavilla Urquí (2009).

The state of São Paulo, which is the focus of this work, has an area of approximately $250,000 \mathrm{~km}^{2}$ with a population of 43 million inhabitants (IBGE 2016). During the last 70 years, numerous outcrops and landscapes were described and researched, and unimaginable amounts of samples were collected and analysed by means of different techniques for studies in mineralogy, petrology, geochemistry, geochronology and structural geology, among others. Several field trips were made as part either of disciplines or of scientific events, each of these containing sites of geological interest that are the best in the specific area. All these sites constitute important pieces in a puzzle that have long been used to tell the geological history of the state.

Unfortunately, the scientific use of many of these sites is currently complicated or even impossible, mainly due to an intense urban development and extreme weathering. Good examples are the outcrops related to the São Paulo Basin, which covers more than $40 \%$ of the São Paulo capital city (Coutinho 1980) and is part of the Continental Rift of Southeastern Brazil (Riccomini 1989), an important regional-scale structure related to the opening of the South Atlantic Ocean. Located at the most urbanised city in Brazil, since around 1925, a great number of underground constructions mainly related to public transport have crosscut its sedimentary sequences (Gurgueira 2013). Despite the fact that much of both geological and geotechnical information about this basin was obtained by drill core samples, these drillings also destroyed most of the lithological records. Nowadays, only a few outcrops are known, and these are restricted to street or road cuts intensely threatened by illegal human occupation.

Another case that can be mentioned is the tourmalinebearing Perus Granite, the only example of an extremely fractionated granite type in the state, composed by pegmatite and aplite alternating banding and rich in incompatible chemical elements $(\mathrm{B}, \mathrm{Li}, \mathrm{U}$ and $\mathrm{Rb}$ ) and peculiar mineralogy, such as tourmaline, uranium phosphates and silicates (Atencio and
Hypolito 1994). These rocks occur as small, decametric to hectometric stocks, and other bodies intruded into Mesoproterozoic metavolcano-sedimentary sequences of the Serra do Itaberaba Group (Azevedo 1994). Atencio and Hypolito (op cit.) have alerted for the extreme urbanisation and quarrying that had already destroyed outcrops mapped in 1940. During decades, these quarries and other small outcrops used to be an obligatory site in any field trip for students of igneous petrology, mineralogy and other subjects. In recent years, the construction of a ring road around the capital has destroyed all these important sites.

Many other examples could be pointed out that reinforces the importance of a geoconservation strategy in São Paulo, the most industrialised state of Brazil and with a high degree of urbanisation - the urban population is about $96 \%$ of the total state population (IBGE). Much of this development comes also from the countryside, which is occupied by extensive agribusiness involving sugar cane, coffee and corn plantations, among others, as well as livestock. All these activities demand a wide service system that includes an intricate net of roads (the transport system in Brazil is essentially road-based) and airports that imply necessarily the modification of the physical environment. This makes the management of geosites a complex and hard task.

The aim of this paper is to describe the methods and present the results obtained by the project 'Geological heritage of the state of São Paulo: identification, conservation and valuation of geosites with scientific value with national and international relevance', which was the first in Latin America to follow a systematic method at a state scale and with the participation of the geoscience community. The project aimed to select geosites that represent the geological history of the state and to set the background for future geoconservation actions. The protection of the selected geosites is essential to preserve the scientific memory of the state and to ensure future research. The project was based at the Institute of Geosciences, University of São Paulo (IGc/USP), and was supported by the Science Without Borders Programme (Project 075/2012 (MEC/CAPES/CNPq) during the period 2013-2015.

\section{Methods}

The definition of the geosite inventory method depends on the main aim of the inventory, which should answer to four main points: the object, the value, the scope and the utility (Lima et al. 2010). For this project, it was decided to identify, select and assess the geological heritage (object) with national or state scientific relevance (value), occurring in the State of São Paulo (scope) as a way to support future proposals for the management and promotion of this natural heritage by the federal, state or municipal nature conservation agencies (utility). 
The method applied in the State of São Paulo, which has an area of 248,222 $\mathrm{km}^{2}$ (just for comparing purposes, a little bit larger than the surface of the UK), was based on the model developed by the European Association for the Conservation of Geological Heritage (ProGEO) in the 1990s (Wimbledon 1996; Wimbledon and Smith-Meyer 2012). Being an inventory focused on the scientific value, the involvement of the geoscientific community was a fundamental asset, comprising researchers from different institutions with a very strong knowledge on the state geodiversity.

\section{Management Structure}

The organisation of this inventory was based on a three-level structure: (1) general coordination, (2) coordination of geological frameworks and (3) expert teams (Fig. 1).

The General coordination of the inventory was made by one researcher from the Institute of Geosciences at the University of São Paulo and one researcher from the University of Minho, Portugal. Additionally, two geologists from a private company (Geodiversity Geological Solutions Inc.) have closely collaborated with the two coordinators, following a requisite of the funding agency that has sponsored the project, seeking the promotion of knowledge transfer between the academic environment and private businesses. The role of the general coordination was (i) to guarantee that the main objectives of the project were completed in due time, (ii) to organise the initial project workshops aiming the definition of geological frameworks, (iii) to ensure that all coordinators of different frameworks were applying the same criteria for the selection and assessment of geosites, (iv) to confirm in the field the maximum number of geosites possible and (v) to collect and organise the data supplied by the coordinators of all geological frameworks.
The Coordination of geological frameworks was assured by geoscientists with a strong scientific knowledge on the theme of each framework, coming from different institutions such as universities, the Geological Survey of Brazil and the State Geological Institute. These leading scientists were responsible (i) to organise the expert teams that were associated to each framework, (ii) to justify and manage all data concerning each geological framework, (iii) to select, characterise and assess representative geosites of each geological framework and (iv) to discuss and deliver all collected information to the project coordinators.

Finally, the Expert teams were composed by geoscientists with experience and knowledge about the geology and geomorphology of a particular area of the state or of a specific site. Their main task was to suggest potential geosites to the coordinators of each geological framework and to supply geological expertise for the characterisation of these sites.

\section{Working Steps}

The inventory project was carried out along 3 years (20132015). Taking into consideration that this was the first systematic geosite inventory done in Brazil at the scale of a state and that the geoscience community was unaware of the methods involved, several steps were taken in order to guarantee its correct implementation.

1. The project coordinators defined the main aims for the geosite inventory and the method that would be used.

2. A general call to researchers based at universities and research institutions was done by means of a letter containing basic information about the subject and aim of the inventory and with an invitation to participate in an introductory workshop open to all geoscientific community.
Fig. 1 Organisational structure to manage the inventory process

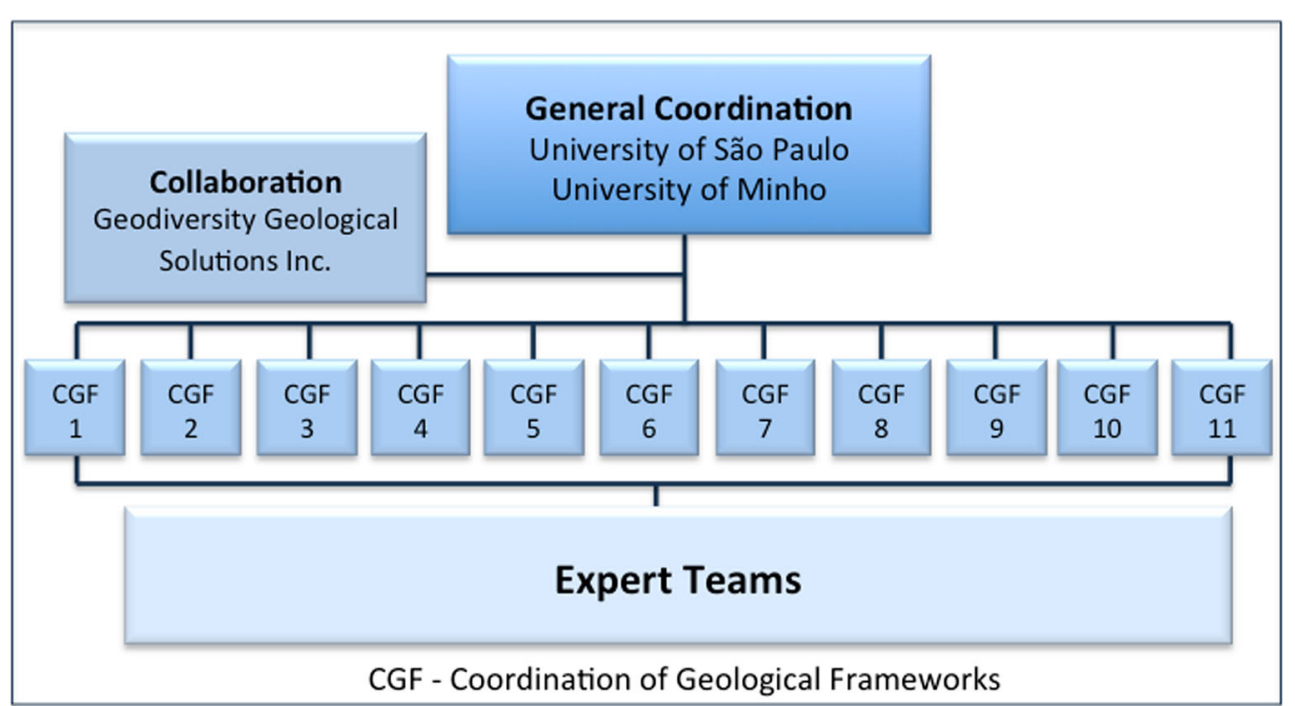


3. The introductory workshop included lectures about the general importance of geoheritage inventories and methods and on the geology of the state of São Paulo. Taking into account the geological setting of the state, during this workshop, a preliminary definition of geological frameworks was discussed, as well as possible coordinators for each one. A second workshop was necessary to conclude the definition of geological frameworks for the state of São Paulo and to define the chronogram and action plan of the inventory.

4. Some complementary information was delivered to all coordinators of geological frameworks, namely the method (criteria/weights) to make the quantitative assessment of the scientific value and risk of degradation of geosites.

5. Field work to characterise and evaluate potential geosites (whenever possible with the participation of the frameworks' coordinators) was carried out along the second half of the project.

6. Additional meetings with researchers from the involved institutions were organised aiming to obtain extra geological information, to discuss concepts related with geoconservation and to debate any further proposals regarding potential geosites.

7. The data obtained from each coordinator of geological framework was integrated in a unique database. This database has information about the geological characterisation of each geosite and the result of the numeric assessment and constitutes the basis for the definition of future management strategies to be implemented by relevant agencies.

\section{Definition of the Geological Frameworks}

In a geoheritage inventory, geological frameworks can be defined as the main subjects that, together, represent the geological history of a specific territory i.e. the records of the main geological/geomorphological events that took place in the studied area (Wimbledon 2011). In this project, the definition of geological frameworks was made by consensus of the geological community invited to participate in two open workshops about the Inventory of the Geological Heritage of São Paulo State, held at the IGc/USP on 22 March 2013 and 15 August 2013. The initial basis for the definition of geological frameworks was the tectono-stratigraphic units of São Paulo, published in the Geological Map of the State of São Paulo (Perrotta et al. 2005). During the project, some adjustments in the frameworks initially established become necessary, since there were no experts available to coordinate some of them. Hence, it was necessary to merge closely related frameworks, without excluding relevant potential geosites that were already pointed out during the workshops or that has resulted from the extensive literature search.

\section{List of Potential Geosites}

Once the geological frameworks and their respective coordinators were established, the listing of potential geosites was initiated. At this stage, it is important to catalogue as many potential geosites as possible, since these geosites will be the basis for a well-based selection. Sites that were already included in the national SIGEP database were included in the list of potential geosites, as well as sites listed in local inventories, like the ones developed in the coastal region of the state of São Paulo (Garcia 2012) and in Rio Claro region (Ribeiro et al. 2013).

In order to systematise the information for each potential geosite, coordinators were provided with a form containing fields to fill with the following:

1. A brief description of the geological framework covering the essential character of that specific part of the geological history of the State of São Paulo, with the main reasons why the framework was chosen to be included in the inventory

2. Information about each proposed geosite including its name (should be a combination of the main geological feature and a geographical reference), location (with GPS coordinates), type (points, viewpoint, section or area), justification of the scientific value (including information about the criteria representativeness, integrity, rarity and scientific knowledge) and identification of possible natural and anthropic threats

\section{Final Selection of Geosites}

A preliminary list containing 193 potential geosites was converted into GIS-based maps and tables, which provided the necessary support for subsequent fieldwork. Some basic assumptions guided the process of changing the status of a geosite from 'potential' to 'definitive':

1. Geosites that were listed in local inventories were analysed according to their previous quantitative assessment and regional relevance. The ones with higher scientific value were included in the inventory.

2. A situation that was recurrent during fieldwork is that some of the potential geosites could not be found. This was due to missing or wrong coordinates, imprecise information regarding former roads or reference spots, urban development and natural factors like weathering and landslides.

3. Some potential sites were repetitions of the same type of geological element/unit. When repetitions were detected, the sites with higher number of relevant geodiversity 
elements, higher integrity or higher number of publications were selected for the final list.

4. Some of the sites published on the SIGEP's volumes, especially on the first one, comprise very large areas, either constituted by a unique homogeneous region or by distinct smaller sites. Taking into account that these SIGEP's sites were not geomorphological sites, their quantitative assessment using the criteria selected for this work was impossible to calculate. For this reason, they were excluded from the inventory.

As a general rule, the primary premise that directed the final selection of geosites was to guarantee the presence of the most representative site within each geological framework.

\section{Quantitative Assessment of Geosites}

Within each geological framework, selected geosites were assessed in order to quantify the scientific value (SV) and degradation risk (DR). This assessment was made using the same principles and methods described in Brilha (2016).
Briefly, the scientific value was evaluated with five criteria: representativeness (30\%), scientific knowledge (15\%), integrity $(25 \%)$, geological diversity $(10 \%)$ and rarity $(20 \%)$. Each criterion has a specific weight considering its relative importance in the evaluation of the scientific value (Tables 1 and 2). A geosite gets a maximum scientific value when, considering the theme of the geological framework where it is included, it is the best representative example in the state of São Paulo; there are international scientific publications about it; there are a great variety of scientifically relevant and well preserved geological elements and it is the only known example in the state of São Paulo.

Similarly, the degradation risk was assessed using the following criteria (Tables 3 and 4): deterioration of geological elements (35\%), proximity to areas/activities with potential to cause degradation (20\%), legal protection (20\%), accessibility $(15 \%)$ and density of population (10\%). The degradation risk of a geosite is maximum when the geological elements have high possibility of deterioration by human and/or natural actions; it is located very close to a potentially degrading area/ activity; it does not have any legal protection nor access control; it has easy accessibility and it is located in an area with a high density of population.
Table 1 Criteria and respective parameters for quantitative evaluation of scientific value
Scientific value

A. Representativeness

The geosite is the best known example in the state of São Paulo to illustrate elements and geological processes associated with geological framework.

points

The geosite is a good example to illustrate elements and processes associated with the geological framework.

The geosite shows fairly elements and processes associated with the geological framework.

2 points

1 point

B. Scientific knowledge

There are scientific publications classified as A1 and A2 by CAPES (the latest update of WebQualis) dedicated to the geosite and associated geological framework.

There are scientific publications classified stratum B1, B2 and B3 by CAPES (the latest update of 2 points WebQualis) dedicated to geosite and associated geological framework.

There are scientific publications classified stratum B4 and B5 by CAPES (the latest update of 1 point WebQualis) dedicated to geosite and associated geological framework.

C. Integrity

Geosite in which the main geological elements associated with the geological framework. Are well preserved.

Geosite with deterioration but that does not affect, in a decisive way, the main geological elements associated with the geological framework.

Geosite with deterioration that hinders the realisation of the main geological elements associated 1 point with the geological framework.

D. Geological diversity

Geosite with more than three types of different geological elements, with scientific value. 4 points

Geosite with three distinct types of geological elements, with scientific value.

Geosite with two different types of geological elements, with scientific value.

2 points

1 point

E. Rarity

The geosite is the only known example in the state of São Paulo, associated with geological 4 points framework.

There are 2 to 3 examples known in the state of São Paulo, associated with geological framework. 2 points

There are 4 to 5 examples known in the state of São Paulo, associated with geological framework. 1 point 
Table 2 Weights of the various criteria for final evaluation of the scientific value of geosites

\begin{tabular}{ll}
\hline Scientific value & \\
\hline Criteria & Weight \\
\hline A. Representativeness & 30 \\
B. Scientific knowledge & 15 \\
C. Integrity & 25 \\
D. Geological diversity & 10 \\
E. Rarity & 20 \\
Total & 100 \\
\hline
\end{tabular}

The results of the numerical assessment are useful for management purposes, namely to establish conservation priorities.

\section{Results}

About 30\% of the São Paulo's territory is composed of crystalline basement (rocks older than Neoproterozoic), while $70 \%$ corresponds to Devonian to Cretaceous deposits of the Paraná and Bauru basins. Intracontinental and coastal Cenozoic basins, as well as Quaternary sedimentary deposits, also occur in minor proportions. Eleven geological frameworks represented by 142 geosites have been identified (Table 5 and Fig. 2). Each geological framework is hereafter described and illustrated by geosites ranked with the highest scientific value (SV).

\section{Precambrian Terranes}

Coordinators are Maria da Glória Motta Garcia and Frederico Meira Faleiros (University of São Paulo).

The Precambrian basement makes up about $30 \%$ of the state of São Paulo and has its general configuration related to the thermo-tectonic events of the Brasiliano-Pan African Cycle, which led to the amalgamation of the Western Gondwana Supercontinent in the Neoproterozoic. The domains that make up the region are included in the Mantiqueira provinces (Ribeira and Apiaí orogens) and Tocantins (southern portion of Brasília Orogen) of Almeida et al. (1981).

The evolution of the orogenic cycle is roughly related to the convergence between the San Francisco, Congo and Paranapanema cratons. Subduction and arc-continent collision and continent-continent processes succeeded continually and were responsible for the amalgamation of several terranes/domains and for the formation of successive magmatic arc suites. The evolution of these terranes described in this paper is based on Campos Neto (2000) and Heilbron et al. (2004).

The terranes of the northeast portion have their evolution related to the Brasília Orogen, being characterised by E-ESEverging nappe systems toward the São Francisco Craton. This Neoproterozoic collisional stage (Collision I, ca. $790 \mathrm{Ma}$ ) is the oldest of Brasiliano Orogeny in the Central Segment of the Mantiqueira Province, reaching its peak in ca. 630-625 Ma.
Table 3 Criteria and respective parameters for quantitative evaluation of vulnerability

\begin{tabular}{ll} 
Vulnerability & \\
\hline A. Deterioration of contents & 4 points \\
Possibility of deterioration of all geological elements & 2 points \\
Decaying possibility of major geological elements & 1 point \\
No possibility of deterioration of the main geological elements & \\
B. Proximity to potentially degrading areas & 4 points \\
Geosite situated less than $50 \mathrm{~m}$ from a potentially degrading activity & 2 points \\
Geosite situated less than $250 \mathrm{~m}$ from a potentially degrading activity & 1 point \\
Geosite situated less than $500 \mathrm{~m}$ from a potentially degrading activity & \\
C. Protection regime & 4 points \\
Geosite located in an area with no system of legal protection and without access control & 2 points \\
Geosite located in an area with no system of legal protection and access control & 1 point \\
Geosite located in an area with legal protection arrangements and access control & \\
D. Accessibility & 4 points \\
Geosite situated less than $100 \mathrm{~m}$ from a road & 2 points \\
Geosite situated between 100 and $500 \mathrm{~m}$ from the road & 1 point \\
Geosite situated more than $500 \mathrm{~m}$ from a road & 4 points \\
E. Density & 2 points \\
Geosite in municipalities with over 1000 inhabitants $/ \mathrm{km}^{2}$ & 1 point \\
Geosite in municipalities with over 166 and less than 1000 inhabitants $/ \mathrm{km}^{2}$ & \\
Geosite in town with less than 166 inhabitants $/ \mathrm{km}^{2}$ &
\end{tabular}


Table 4 Weights of the various criteria for final evaluation of the scientific value of geosites and ranges for classification of vulnerability

Vulnerability

\begin{tabular}{ll}
\hline Criteria & Weight \\
\hline A. Contents & 35 \\
B. Proximity to potentially degrading areas & 20 \\
C. Protection scheme & 20 \\
D. Accessibility & 15 \\
E. Density & 10 \\
Total & 100 \\
Weighed total & \\
$<2$ & Low vulnerability \\
$2.1-3$ & Medium vulnerability \\
$3.1-4$ & High vulnerability \\
\hline
\end{tabular}

These are represented by the Socorro-Guaxupé Nappe and the Andrelândia Terrane.

The terranes of the south-southeast portion are characterised by NE-SW-oriented units, which present evidence of a complex diachronic evolution. Contrasting lithologic associations, metamorphic and structural styles are separated by high-angle, strike-slip shear zones associated with Ribeira and Apiaí orogens. This second continental collision stage (Collision II, ca. $580 \mathrm{Ma}$ ) resulted in the east to westnorthwest stacking of nappes. In the state of São Paulo, this portion is represented by the Luis Alves, Curitiba, Paranaguá, Serra do Mar, Embu, Juiz de Fora and Apiaí-São Roque terranes.

Table 5 Geological frameworks defined for the inventory of geological heritage of the state of São Paulo, Brazil, and number of geosites for each framework

\begin{tabular}{lll}
\hline Geological frameworks & $\begin{array}{l}\text { Number } \\
\text { of potential } \\
\text { geosites }\end{array}$ & $\begin{array}{l}\text { Number } \\
\text { of selected } \\
\text { geosites }\end{array}$ \\
\hline Precambrian terranes & 32 & 21 \\
Shear zones & 13 & 09 \\
Granitic rocks & 11 & 10 \\
Precambrian metallic mineralisation & 09 & 07 \\
Paraná Basin & 31 & 23 \\
Mesozoic magmatism & 18 & 13 \\
Bauru Basin & 16 & 15 \\
Continental Rift of Southeastern Brazil & 12 & 10 \\
Continental and coastal Neogenic and & 11 & 06 \\
Quaternary evolution & 15 & 14 \\
Geomorphological units and landforms & 15 & 14 \\
Caves and karst systems & 26 & 142 \\
Total & 193 & \\
\hline
\end{tabular}

In this context, terranes with different geological histories were gradually incorporated into the newly formed land masses and pre-Brasiliano units are found throughout the area. The Archaean oldest rocks are represented by polycyclic migmatites of the Amparo Complex (3000-2700 Ma) and from the infrastructure of nappes in the Andrelandia Terrane. Palaeoproterozoic remainings associated with the Transamazonian Cycle, aged 2200-2100 Ma, are represented by the Serra Negra, Atuba, Itatins and Apiaí Mirim complexes and represent orogen fragments characterised by juvenile accretion with abundant TTG plutonism and continental or transitional arc-type potassic rocks. The San Roque Group represents a vulcanossedimentar basin deposited in the Estaterian (1750-1700 Ma). The Mesoproterozoic record is characterised by the metavolcanosedimentary successions of the Água Clara Formation (1500 Ma) and of the Votuverava (1500 Ma) and Serra do Itaberaba (1400-1200 Ma) groups, related to old retroarc basins. The Embu Terrane (accreted in $605-580 \mathrm{Ma}$ ) is predominantly formed by successions of supracrustal medium to high metamorphic grade deposited in the Tonian (between 950 and $790 \mathrm{Ma}$ ). Neoproterozoic sedimentary basins developed or clumped in the Paranapanema block, nowadays covered by the sedimentary rocks of the Paraná Basin, occur in the Curitiba (Turvo-Cajati formations and Capiru) and Guaxupé terranes. Finally, strikeslip late-tectonic basins, associated with the collisional events, are represented by the Eleutério, Pico de Itapeva, Iporanga, Samambaia and Quatis formations. Representative geosites are shown in Fig. 3.

\section{Shear Zones}

Coordinators are Maria da Glória Motta Garcia and Ginaldo Campanha (University of São Paulo).

The structural organisation of the Precambrian terranes of Southeastern Brazil is related to the evolution of the Mantiqueira Province, developed during the Brasiliano-Pan African Orogeny, which in turn resulted in the amalgamation of the West Gondwana Supercontinent in the Neoproterozoic (Heilbron et al. 2004). In the region, units made up of portions of reworked basement, supracrustal rocks and orthoderivate rocks occur as elongated strips bounded by strike-slip shear zones that can include thrust components. The whole megastructure reaches about $1000 \mathrm{~km}$ length and $200 \mathrm{~km}$ wide, with a probably total slip of hundreds of kilometres (Campanha 2002). In the northern portion of the province (Araçuaí Orogen), the structures are preferably NS-oriented, changing to NE-ENE in the central region (Ribeira and Apiai orogens and southern portion of the Brasília Orogen) and returning to the general direction NS in the southern part of Brazil until Uruguay (Dom Feliciano and São Gabriel orogens). 


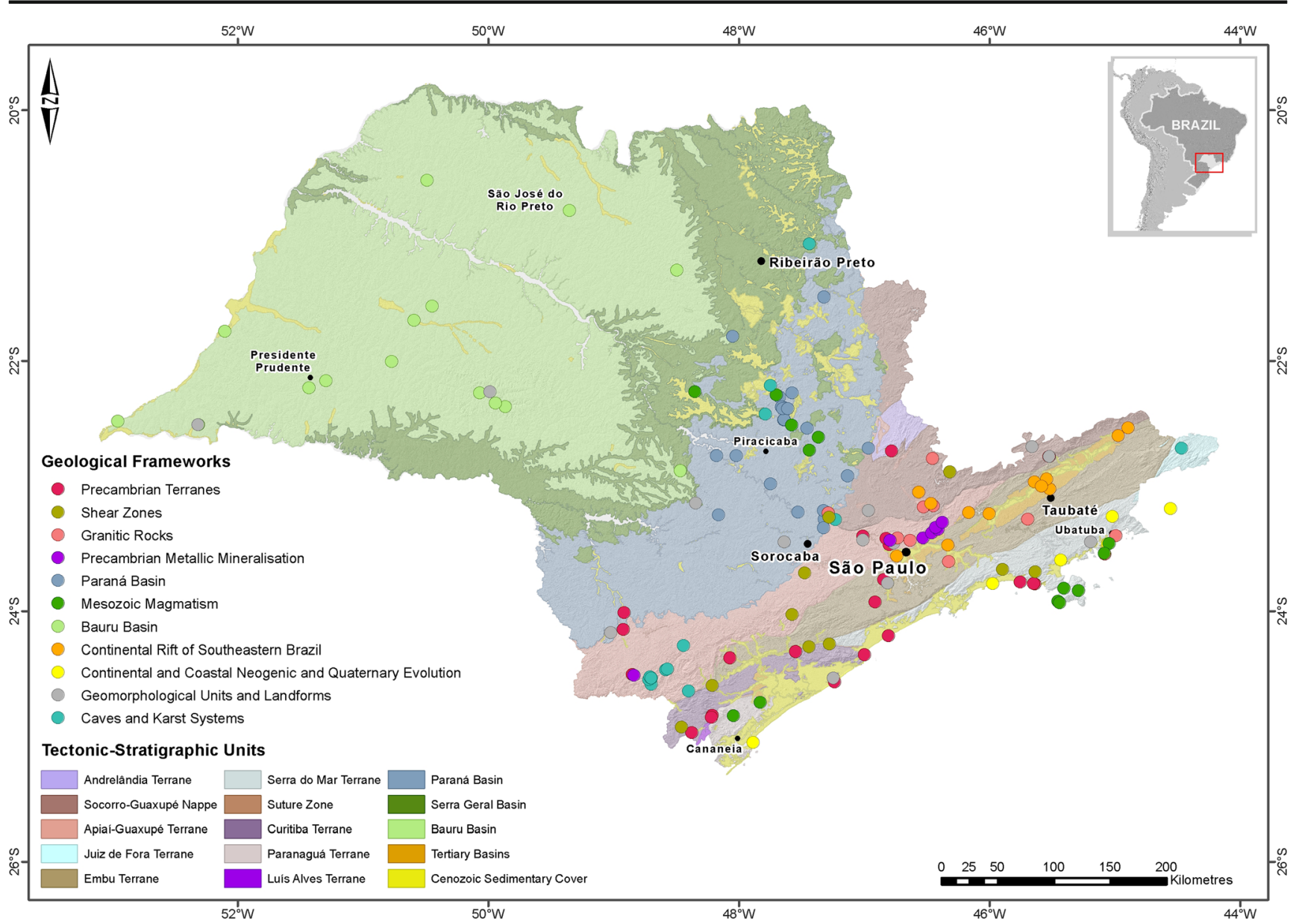

Fig. 2 São Paulo State tectonic-stratigraphic unit map showing the geosite location according with the geological framework (tectonic-stratigraphic units from Perrotta et al. 2005)

This shear zone system was possibly formed by escape tectonics in response to the oblique collision during the Brasiliano-Pan African orogeny (Heilbron et al. 2004), resulting in strong transpressive dextral components. Its role in lithostructural, stratigraphic and tectonic organisation of the Mantiqueira Orogenic System is important because it juxtaposes terranes with different geological histories, in some cases corresponding to eventual palaeosutures. These structures are parallel to the shoreline and constrain the rift system that evolved during the fragmentation events of Western Gondwana, in the Cretaceous and Tertiary.

In the portion that includes the state of São Paulo, in the central sector of the shear zone system, the structures are predominantly dextral. The fault/shear zones are characterised by upright foliation and sub-horizontal stretching lineation along mylonitic zones whose thickness may reach $1000 \mathrm{~m}$ (Campanha 2002). Two major systems are considered important crustal limits: the Paraíba-Cubatão-Itapeúna-Lancinha and the Jundiuvira-Buquira-Rio Preto. Apart from these, shear zones such as Taxaquara, Alto da Fartura, Caucaia and Extrema, among other smaller, are the records of the oblique collision movements that characterise the region. Some examples of these structures are represented in this framework. Representative geosites are shown in Fig. 4.

\section{Granitic Rocks}

Coordinators are Lucelene Martins, Valdecir de Assis Janasi and Adriana Alves (University of São Paulo).

The crystalline basement of the state of São Paulo is made up of old Archaean to Proterozoic igneous and metamorphic rocks outcropping along an elongated belt in the ESE portion of the state. To the west, these rocks are covered by the extensive Phanerozoic sedimentary sequences of the Paraná Basin. Faults along hundreds of kilometres crosscut the basement, juxtaposing blocks of continental crust in an intricate mosaic of geological domains.

There are more than 200 kilometric to metric bodies, associated with extensional tectonics and collisional events during the Neoproterozoic (Janasi and Ulbrich 1992). Radiometric dating of these rocks shows that the peak of partial melting of the continental crust occurred in the Neoproterozoic (about $600 \pm 50 \mathrm{Ma}$ ). These granitic rocks represent a significant part of the geological record of the South American Platform, 


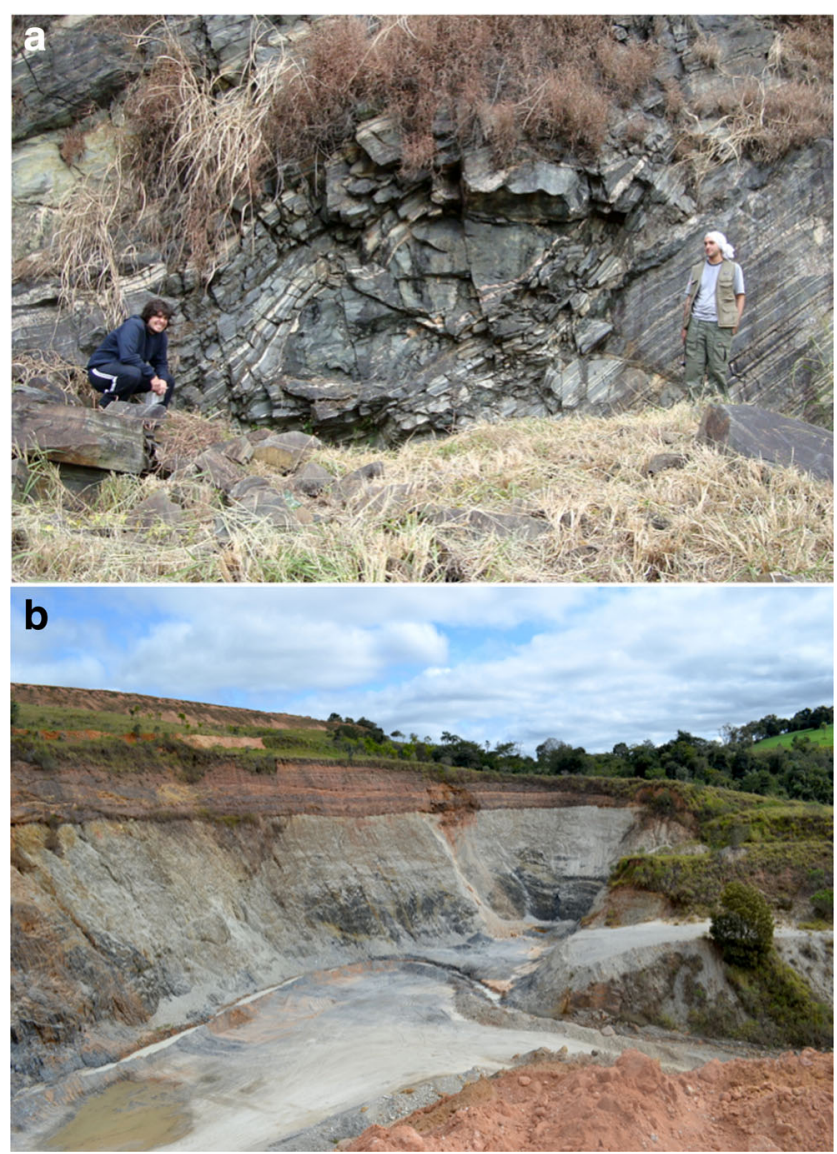

Fig. 3 Selected geosites of the geological framework 'Precambrian Terranes'. a Geosite 'Atuba Complex at the Serra do Azeite'. The Atuba Complex was formed in the Archaean and later migmatised in the Palaeoproterozoic (ca. $2100 \mathrm{Ma}$ ) and Neoproterozoic (ca. $600 \mathrm{Ma}$ ). The region of Serra do Azeite contains the best outcrops related to this unit. The photo shows mylonitic grey banded gneisses in the section parallel to the stretching lineation (Faleiros et al. 2011). SV: 3.80. b Geosite 'Contact between Itaiacoca Group and Furnas Formation in Itapeva'. This feature represents an erosional discordance that limits the Devonian fluvial sequence of the Furnas Formation at the base of Paraná Basin and the underlain Mesoproterozoic metavolcano sedimentary sequence of the Itaiacoca Group. SV: 3.70

namely collision of tectonic plates and development of mountain ranges during the Neoproterozoic-Cambrian (800$500 \mathrm{Ma})$.

Each type of granite helps to understand part of the evolutionary history of the crystalline basement of São Paulo. Thus, based on the available data (geological distribution, composition, and age), the proposed geosites seek to emphasise their diversity and scientific relevance. Representative geosites are shown in Fig. 5.

\section{Precambrian Metallic Mineralisations}

Coordinator is Annabel Pérez-Aguilar (Geological Institute, State of São Paulo).
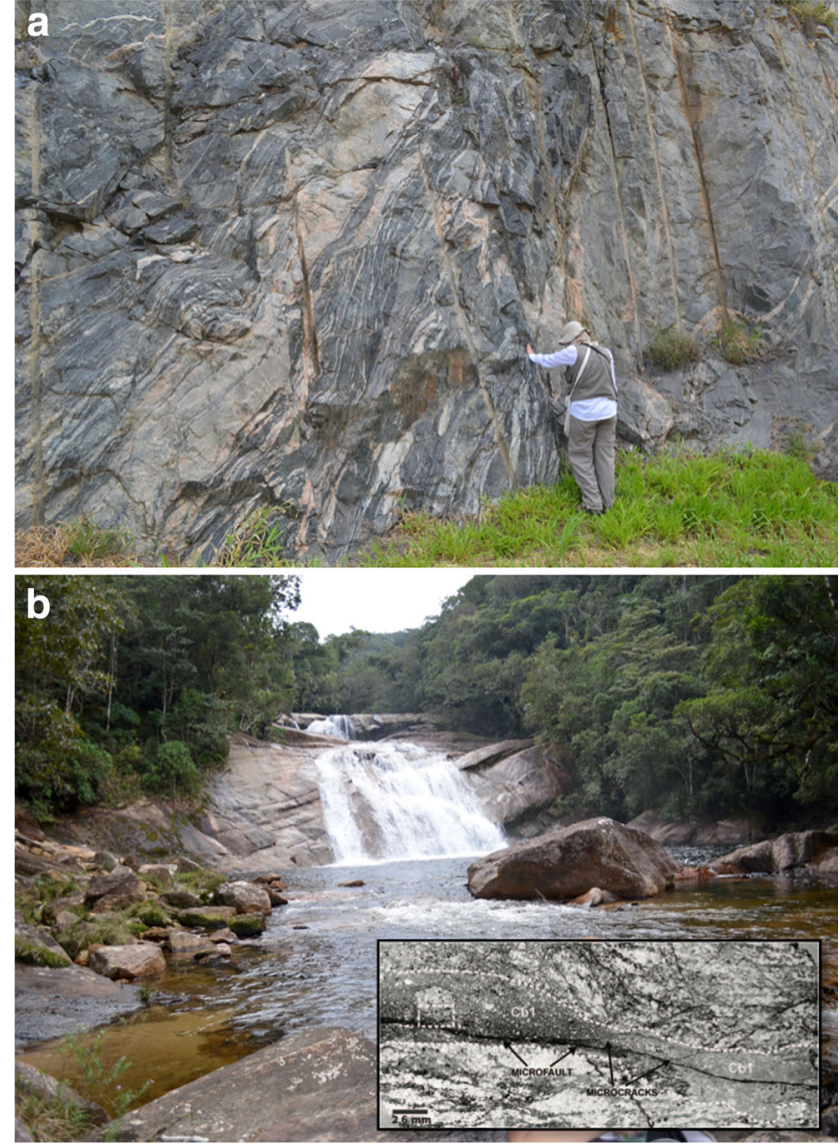

Fig. 4 Selected geosites of the geological framework 'Shear Zones'. a Geosite 'Mylonites from the Itu Shear Zone'. In this outcrop, the shear zone affects migmatitic gneisses from the Varginha-Guaxupé Complex and also records ductile deformation prior to shearing. Photo: L. Martins. SV: 3.55. b Geosite 'Mylonites and cataclasites from the Camburu Shear Zone'. This shear zone separates two lithologic types of the Precambrian Coastal Domain: the Pico do Papagaio Granite to the NW of the fault and the Juqueí Augen Gneiss to the SE; it is composed by quartz-feldspathic mylonitic rocks intercalated with cemented cataclastic rocks (Campanha et al. 1994, Mora et al. 2013). SV: 3.30

The Precambrian rocks of the State of São Paulo are part of the central segment of the Ribeira Fold Belt (Almeida et al. 1981). In this context, the Serra do Itaberaba Group outcrops in the proximities of São Paulo city and corresponds to a Mesoproterozoic metavolcano-sedimentary succession (Juliani 1993; Juliani et al. 2000), which was initially deposited in an oceanic environment with N-MORB-type basalts. Later deposition on a retroarc environment generated hydrothermal/exhalative palaeo-systems, genetically linked to the placement of small andesite to rhyolite bodies (Juliani 1993; Pérez-Aguilar et al. 2005, 2011; Beljavskis et al. 1999; Garda et al. 2002). These systems developed advanced argillic alteration zones by magmatic-hydrothermal fluids related to syngenetic high-sulfidation gold mineralisation, with topazschists as metamorphic products (Juliani et al. 1994; PérezAguilar et al. 2011, 2014). Exhalative activity was responsible for the genesis of both tourmaline-bearing rocks and iron 

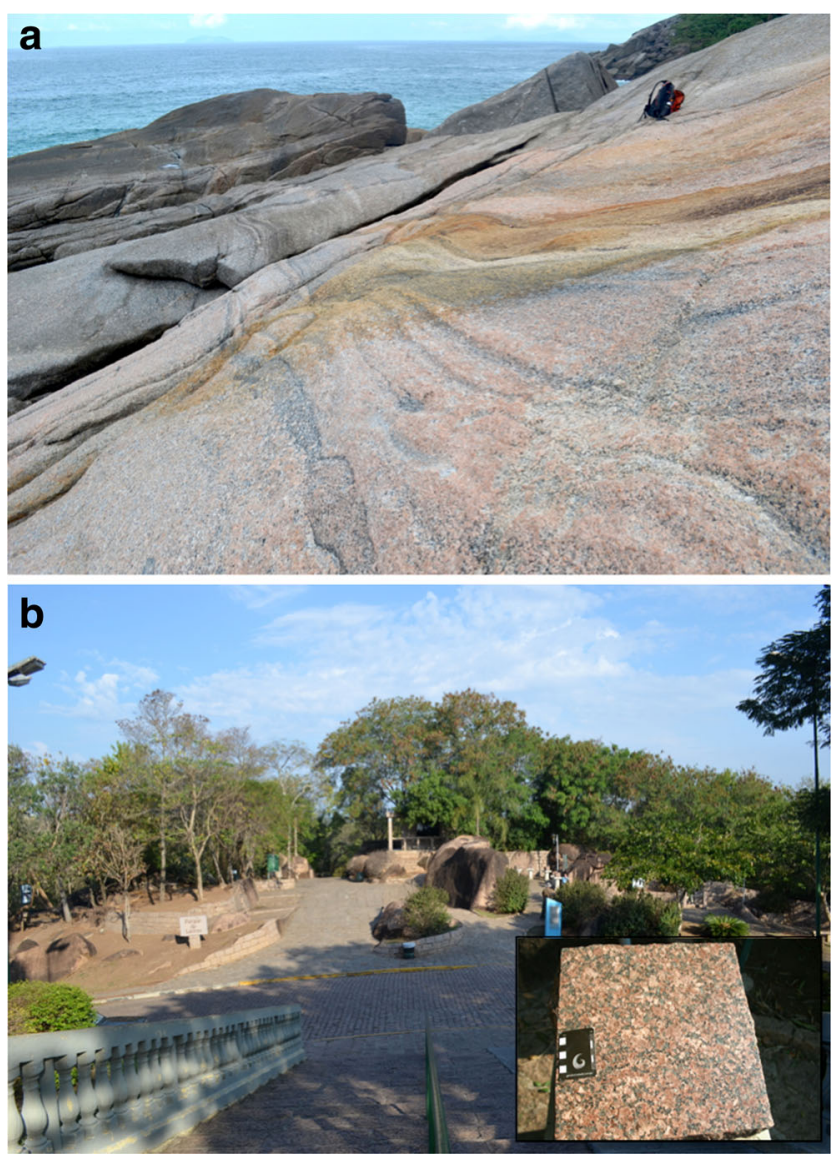

Fig. 5 Selected geosites of the geological framework 'Granitic Rocks'. a Geosite 'Ilha Anchieta late post-collisional monzogranite'. The 500-Ma lithotype occupies most of the homonymous island and is intrusive into the $\sim 565-\mathrm{Ma}$ Ubatuba Charnockite. It records the final stages of Gondwana assembly in the Neoproterozoic, represented by the Búzios Orogeny, the last event before the opening of the South Atlantic Ocean. SV: 3.40. b Geosite 'Rapakivi granite from the Itu Granitic Province in Lavras'. The Itu granitic batholith is composed of four major postcollisional intrusions (590 and $565 \mathrm{Ma}$ ), which outcrop in an area of $310 \mathrm{~km}^{2}$. It represents an A-type granitogenesis, with well-developed rapakivi texture interpreted as a result of magma mixtures with mafic composition. SV: 3.30

mineralisation. When metamorphosed, these protoliths produced tourmalinites and the metamorphic product of Algoma-type iron formation, both enriched with syngenetic gold mineralisation (Juliani 1993; Garda et al. 2003, 2005, 2009; Beljavskis et al. 2003, 2005). Within this group, lowangle epigenetic shear zone-related gold mineralisation also occurs due to remobilisations of syngenetic gold (Martin et al. 1998).

Gold mining during the colonial period of rocks and associated sediments from the Serra do Itaberaba Group is registered in several archaeological structures such as dams, pipelines, tunnels, mining benches, mining fronts, channels, ditches, gold washing and separation areas, waste gravel piles, traces of stone walls and armholes of up to several hundred metres long (Carneiro 2000; Carneiro et al. 2011; Pérez-
Aguilar et al. 2012a; Pérez-Aguilar et al. 2012b; PérezAguilar et al. 2013).

Palaeohydrothermal systems that affected rocks from the Serra do Itaberaba Group were also responsible for the presence of large chloritic alteration zones that variably altered basic, intermediate and acid volcaniclastic and igneous rocks. The metamorphic products include weakly, transitional, moderately and strongly hydrothermally altered rocks, which typically have $\mathrm{Mg}$ amphibole(s). Rocks are referred to as cummingtonite/anthophyllite rocks. Strongly altered rocks are mainly composed of cummingtonite/anthophyllite \pm cordierite \pm garnet \pm quartz (Pérez-Aguilar et al. 2000, 2005, 2007), being similar to those described as associated with metamorphosed volcanogenic massive sulphide deposits (e.g. Elliot-Meadows and Appleyard 1991). Massive sulphide deposits have not yet been found, although soil geochemical anomalies of copper and zinc have been identified (Juliani 1993).

In the southern part of the state of São Paulo outcrops the Água Clara Formation, of Mesoproterozoic age, which corresponds to a metavolcano-sedimentary sequence deposited in a platform environment with predominance of marble (Araújo 1999; Weber et al. 2004). Near the town of Apiaí, in the locality known as Morro do Ouro, syngenetic gold mineralisation occurs in sulphide-bearing metachert lenses intercalated within metasediments, as well as epigenetic gold mineralisation in sulphide-rich quartz veins that crosscut these metasedimentary rocks (Paiva and Morgental 1980; Faleiros et al. 2014). Representative geosites are shown in Fig. 6.

\section{Paraná Basin}

\section{Coordinator is Frésia Ricardi-Branco (University of Campinas).}

In the state of São Paulo, rocks resulting from the glacialinterglacial cycle occurred in the southern portion of the Gondwana palaeocontinent during the Upper Carboniferous-Lower Permian interval (Limarino et al. 2014; Christiano-de-Souza and Ricardi-Branco 2015). These events significantly conditioned the sedimentary record, known as Itararé Group, as well as the evolution of flora and fauna associated with the Paraná Basin. Significant records of these glacial and interglacial events are evidenced in the form of fossil assemblages mainly composed of plants, as well as the abrasion features from the glacial fronts, and their liquefaction during interglacial intervals (Santos et al. 1996; Milani et al. 2007).

With the end of the Permian glaciation, the basin experienced a continentalisation that culminated with the installation of a continental environment at the end of the Permian (Rohn 2007). In terms of sedimentary and fossil records, it is extremely well documented in rock sequences associated with the Passa Dois Group (Irati 

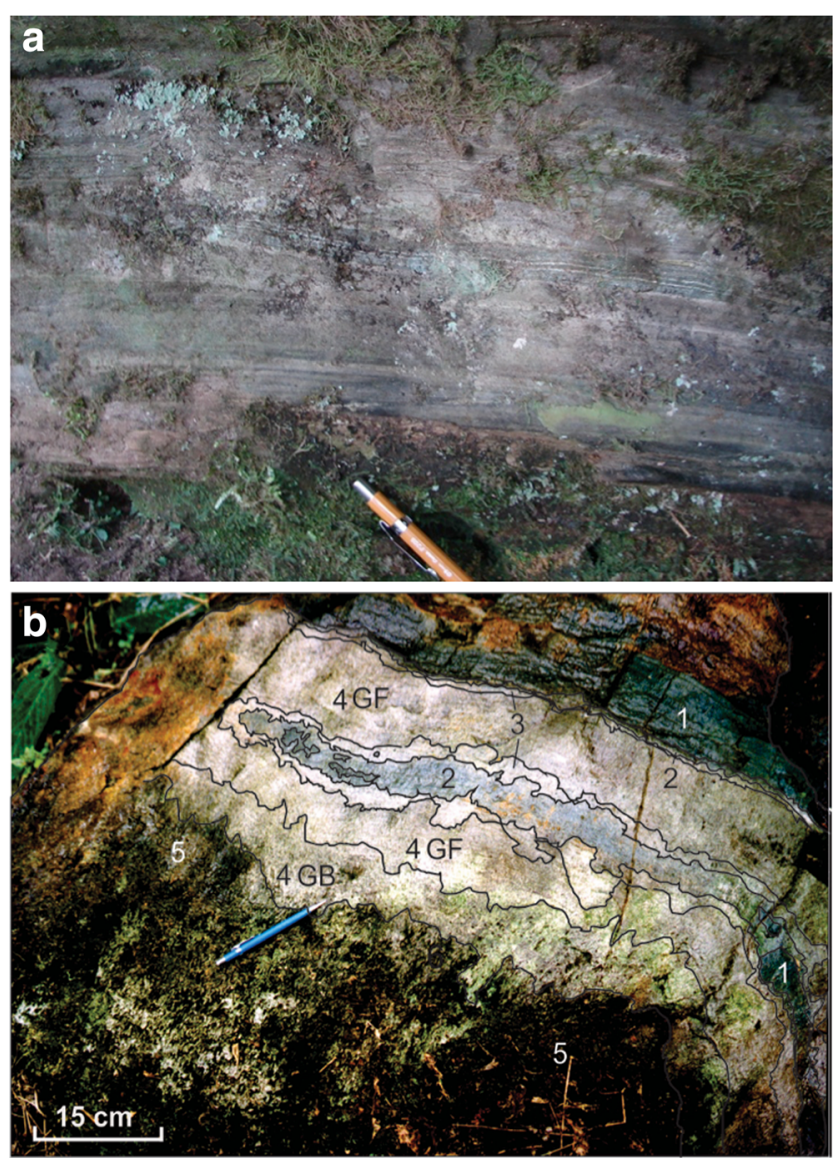

Fig. 6 Selected geosites of the geological framework 'Precambrian Metallic Mineralisations'. a Geosite 'Fazenda Soledade Tourmalinites'. Outcrop showing exhalative-sedimentary tourmalinites with alternating tourmaline-rich (black) and quartz-rich (white and whitish) beds; SV: 3.80. b Geosite 'Itaberaba cummingtonite/anthophyllite rocks'. Metavolcaniclastic rocks with variably hydrothermally altered lithotypes related to a chloritic alteration zone: 1 weakly altered rocks, 2 transitional altered rocks with hornblende predominating over cummingtonite, 3 transitional altered rocks with cummingtonite predominating over hornblende, $4 G F$ garnet-free and $4 G B$ garnetbearing moderately altered rocks, and 5 strongly altered rocks. Dark lines represent boundaries between different altered lithotypes (PérezAguilar et al. 2005). SV: 3.70

Subgroup and Teresina, Serra Alta, Corumbataí and Rio do Rasto formations). Thus, lithostratigraphic units related to the Permian show the record of a warm, shallow sea that was gradually silt up, increasing the influence of freshwater (Rohn 2007). This basin continentalisation followed a worldwide trend of aridity due to the assembly of Pangaea (Linol et al. 2015), a good reason to preserve some of the outcrops related to this event.

Finally, during the Mesozoic, the portion of western Gondwana, where the basin is located, experienced arid climates that completed the tendency to continentalisation, which started in the Permian. The desert climate is characterised by extensive dune fields that at the end of Jurassic alternated with basaltic flows arising from the separation of Africa and South America and the consequent opening of the South Atlantic Ocean, which concludes the sedimentary history of the Paraná Basin (Linol et al. 2015). Excellent outcrops recording the events and associated life may be found throughout the interior of São Paulo state. Representative geosites are shown in Fig. 7.

\section{Mesozoic Magmatism}

Coordinators are Maria Irene Bartolomeu Raposo and Maria da Glória Motta Garcia (University of São Paulo).

Southeastern Brazil was the scenario of intense tectonicmagmatic processes during the Mesozoic to Cenozoic. The magmatism is represented mainly by the (i) basaltic flows of the Serra Geral Formation (Paraná Basin) so known as
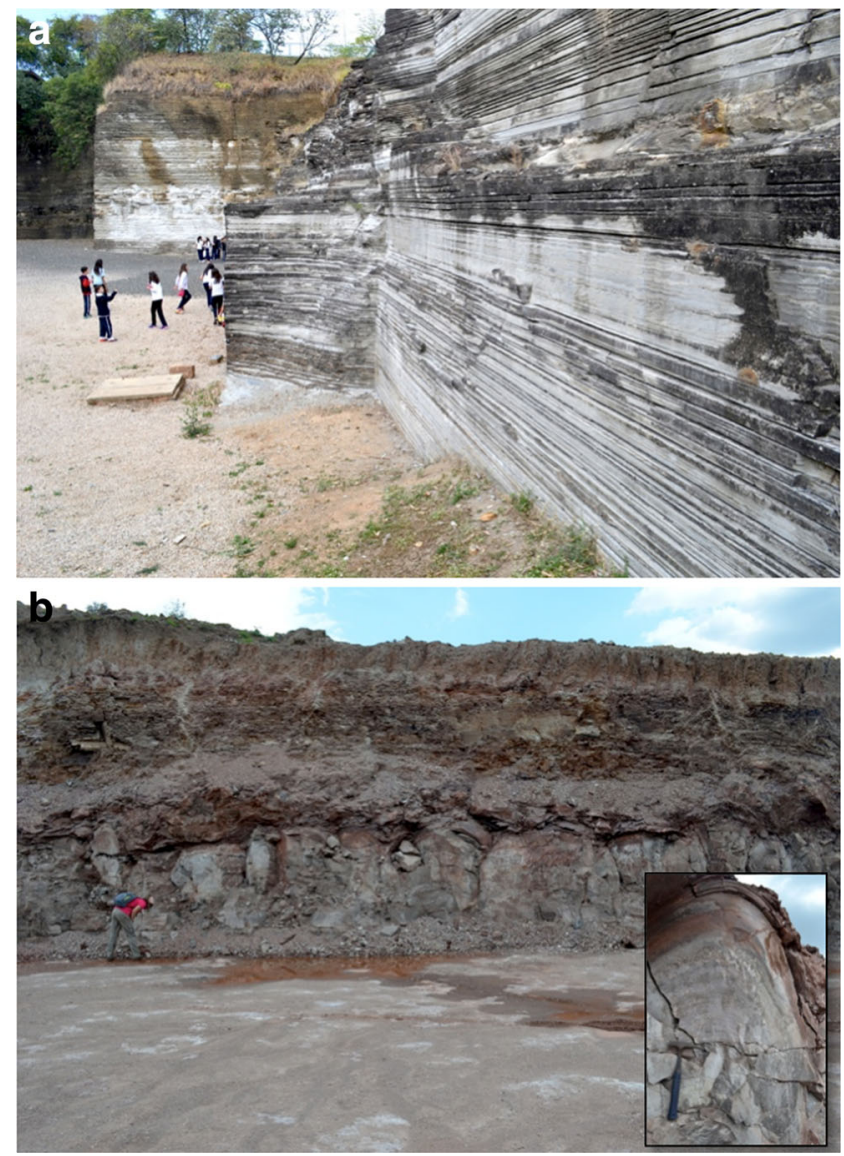

Fig. 7 Selected geosites of the geological framework 'Paraná Basin'. a Geosite 'Varvite of Itu'. The Itu quarry constitutes the best exposure of glacial rhythmite from the Itararé Subgroup known in the Paraná Basin. It represents a classic geological monument related to the Late Palaeozoic glaciation, which is well preserved within the municipality of Varvito Park (Rocha-Campos 2002). SV: 3.80. b Geosite 'Giant stromatolites of Santa Rosa de Viterbo'. This excellent outcrop is located within a quarry and constitutes a record of the Permian Irati Subgroup, deposited under restricted ocean conditions, progressively saltier and drier. The area is covered with over $3 \mathrm{~m}$ of stromatolite domes, formed in carbonate rocks under coastal conditions (Ricardi-Branco et al. 2006). SV: 3.70 
Paraná-Etendeka Province, which is the second largest Cretaceous continental flood basalt of the world; (ii) dike swarms from the Ponta Grossa Arch, Florianópolis and along the coast between São Paulo and Rio de Janeiro and (iii) several alkaline complexes that lie along tectonic features associated with the evolution of the Paraná Basin. The emplacement of the dike swarms and the alkaline complexes is related to the breakup of the Gondwanaland Supercontinent and the processes of the opening of South Atlantic Ocean, which resulted in the evolution of the Brazilian Atlantic continental margin. ${ }^{40} \mathrm{Ar} /{ }^{39} \mathrm{Ar}$ ages suggest that the Paraná-Etendeka magmatism climaxed between 130 and $134 \mathrm{Ma}$ (Turner et al. 1994; Renne et al. 1996), with the installation of the Ponta Grossa Arch dykes (NW-oriented) and later along the coasts of Santa Catarina, São Paulo and Rio de Janeiro states all of them NE-oriented. The tholeiitic dike swarms were developed in the Florianópolis region with ${ }^{40} \mathrm{Ar} /{ }^{39} \mathrm{Ar}$ ages in the range of 124-129 Ma (Raposo et al. 1998; Deckart et al. 1998) and along the coast of the São Paulo and Rio de Janeiro states with ${ }^{40} \mathrm{Ar} /{ }^{39} \mathrm{Ar}$ ages in the range of 129-130 (Renne et al. 1996; Turner et al. 1994).

Dike swarms from coastline of São Paulo state are widespread along Serra do Mar between São Paulo and Rio de Janeiro states. The swarms occur also along the coast in the Ilhabela Island (NE of São Paulo state). The swarms crosscut Proterozoic polymetamorphosed rocks of the Costeiro Complex and alkaline stocks. The dikes are basic, intermediate, alkaline and lamprophyres in composition, and they crop out side by side in the beaches and cliffs. They range from a few centimetres up to $10 \mathrm{~m}$ wide, and their trend is predominately N40-50E with vertical dips. It is believed that the basaltic activity occurred during the Early Cretaceous was partly coeval with Ponta Grossa and Florianópolis dikes (e.g. Almeida 1986); however, the other dikes are younger than the basalts (Almeida 1986). Representative geosites are shown in Fig. 8.

\section{Bauru Basin}

Coordinator is Luiz Alberto Fernandes (Federal University of Paraná).

In São Paulo state, the Cretaceous is mainly represented by the Upper Cretaceous continental sandstones (99.6 to $65.5 \mathrm{Ma}$ ) from the Bauru Basin. They constitute about $45 \%$ of the territory corresponding to a great part of the substrate of the centre-western region of the state.

The Bauru Basin was formed within the South American platform, after the breakup of Gondwana and opening of the South Atlantic Ocean, and corresponds to a period of isostatic adjustment subsidence due to the basaltic accumulation of the Serra Geral Formation in the Early Cretaceous (Fernandes and Coimbra 1996). The basin was filled by an essentially sandy
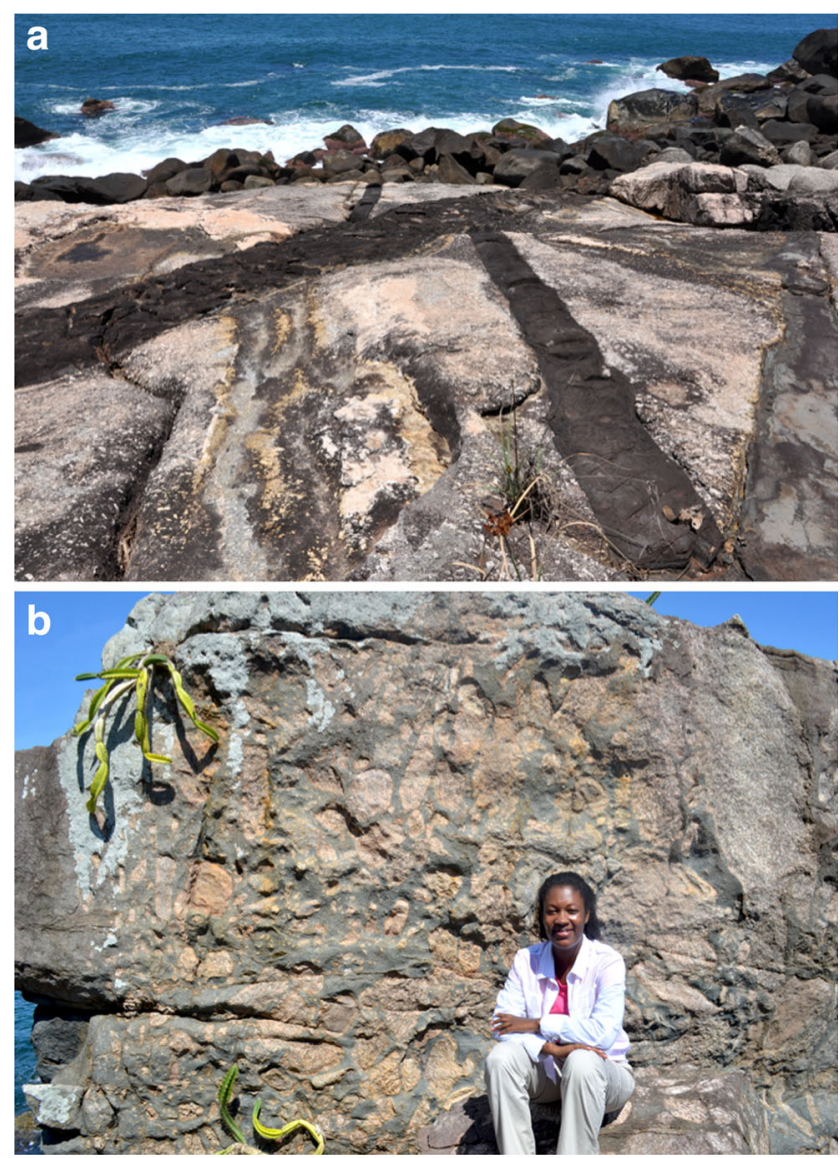

Fig. 8 Selected geosites of the geological framework 'Mesozoic Magmatism'. a Geosite 'Ilhabela Dykes'. These features are found within an area of about $4000 \mathrm{~m}^{2}$ along the rocky shore of the island of Ilhabela. Lamprophyre and diabase Mesozoic dykes intrude porphyritic granite from the Precambrian Costal Domain and show complex crosscutting relationships that reveal important information about the stress fields related to the breakup of the West Gondwana Supercontinent. SV: 3.70. b Geosite 'Anchieta Island magmatic breccias'. This feature occurs at the western portion of Anchieta Island and is associated to tholeiitic dykes of the Cretaceous coastline swarm ( 140-134 Ma). The magmatic breccia is produced by the interaction between the basaltic magma and the enclosing foliated charnockites and granites. It is exposed over an area of tens of metres (Azevedo Sobrinho et al. 2011). SV: 3.70

siliciclastic sedimentary sequence formed by sandstones and reddish siltstones (red beds), under semi-arid conditions, in the borders and desertic ones, in the southwest. It has preserved maximum thickness of about $480 \mathrm{~m}$ in the north of Paraná state. In lithostratigraphic terms, the sequence is composed of the Caiuá and Bauru groups (Fernandes and Coimbra 2000), of Upper Cretaceous age, between Coniacian and Maastrichtian.

The palaeogeographic context of the Bauru Basin included marginal alluvial fans that supply the sediment to form wide plains of sand sheets crosscut by interlocking river systems, with ephemeral lakes of alkaline waters in areas with increased availability of water (Milani et al. 2007). In these sectors, reptiles, especially dinosaurs, crocodiles, turtles and 
invertebrates, were common (Fernandes and Magalhães Ribeiro 2015). The increasing degree of aridity to the interior of the basin determined the gradual reduction in the development and preservation of the palaeontological record in the inner units, up to its almost absence in erg-type deposits inside the palaeodesert named Caiuá (Fernandes 2006). In the regions of Marília and Monte Alto, there is the greatest diversity of fossil records of the Bauru Basin, as well as the greatest number of larger individuals.

Besides constituting almost half of the state territory substrate, the Upper Cretaceous continental sequence corresponds to the registers of a geological period of fundamental importance in the understanding and the interpretation of the geological history of the state. It corresponds to the scenario of life and extinction of remarkable fauna of reptiles such as dinosaurs and crocodiles, as well as turtles and invertebrates. Under the geomorphological point of view, there are the plateaus and slopes of the regions of Marília and Monte Alto, as well as the hill Morro do Diabo, in the far west of the state. The Cretaceous period is a natural case of greenhouse in the history of the planet, whose systemic understanding is of fundamental importance for future studies of global climate change. Representative geosites are shown in Fig. 9.

\section{Continental Rift of Southeastern Brasil}

Coordinators are Maria Judite Garcia and Maria da Glória Motta Garcia (University of São Paulo).

The Continental Rift of Southeast Brazil-CRSB (Riccomini 1989) - has its evolution related to the latest stage of the tectonic activation event in the South American Platform, associated with the fragmentation of the Gondwana supercontinent and the formation of the South Atlantic Ocean. The CRSB is a tectonic feature of Cenozoic age, which lies between the towns of Curitiba in Paraná and Barra de São João in Rio de Janeiro. It occurs as an over 900$\mathrm{km}$ narrow, depressed strip, elongated in the ENE direction, parallel to the coastline. The rift can be divided into three segments: Western, Central and Eastern (Riccomini et al. 2004).

The installation of the rift is related to the final stages of the evolution of Serra do Mar, the most important orographic feature of the South American Continent Atlantic border. Reactivation of Neoproterozoic shear zones by predominantly normal faults caused the uplift and abatement of crustal blocks, creating a rift parallel to the coastline (Riccomini et al. 2004). Evidence from basement rocks indicates a sinistral strike-slip regime, associated to NE-SW compression and NW-SE distension. This sinistral strike-slip regime preceded the distensive NNW-SSE event, responsible for the installation of the basins.

In the state of São Paulo, the CRSB is represented by the sedimentary basins of Taubaté and São Paulo, included in the central segment of the structure (Riccomini et al. 2004) and settled on Palaeoproterozoic to Neoproterozoic igneous and metamorphic rocks of the Ribeira Fold Belt (Hasui and Ponçano 1978). The first one corresponds to an asymmetric basin formed by inwardly depressed and uplifted regions. Its elongated shape is conditioned by ENE-oriented old discontinuities, which favoured a reactivation tectonics (Fernandes 1993; Fernandes and Chang 2001). The São Paulo Basin was probably developed from a hemigraben with limits controlled by normal faults, which are reactivations of the Proterozoic Taxaquara and Rio Jaguari shear zones, to the north (Riccomini et al. 2004). However, due to intense urbanisation, few outcrops are currently available. It is assumed that the individualisation of both basins is later to CRSB installation events. Selected geosites to integrate the inventory cover the main sedimentary record and the main generator and deforming events, as well as fossil records. Representative geosites are shown in Fig. 10.

\section{Continental and Coastal Neogenic and Quaternary Evolution}

Coordinators are Wânia Duleba (University of São Paulo) and Célia Regina Gouveia de Souza (Geological Institute, state of São Paulo).

The coast of the state of São Paulo is included in the Coastal Province, which is divided into two large geological-geomorphological compartments: the Coastal Mountain Range ('Serrania Costeira') and the Coastal Plain ('Baixada Litorânea') (Almeida 1964).

The Coastal Mountain Range consists of the Serra do Mar structural escarpment at the edge of the Atlantic Plateau and some isolated hills on the coastal plains. It is mainly composed of Precambrian metamorphic rocks and granitic bodies, which were cut by Jurassic basic dikes and sills and Cretaceous alkaline intrusions (Almeida and Carneiro 1998; Almeida et al. 2000; Zalan and Oliveira 2005).

The Coastal Plain consists of marine-beach deposits intercalated and interdigitated by alluvial, aeolian, estuarine, lagoon and palustrine sediments with ages ranging from the Quaternary to the present (Suguio and Martin 1978; Souza et al. 2008). The beaches that limit these plains present distinct morphodynamic states (Souza 2013).

The current coastal physiography results from a sequence of events controlled by geological, geomorphological, climatic and oceanographic processes that determined the evolution of the coastal basement, the genesis and development of the watershed basins and the coastal plains and the consolidation of the current coastline and beaches (Souza 2015). Two main events marked this chain of processes. The first one began at the end of the Cretaceous and is related with brittle tectonics, which resulted in the uplift of the Serra do Mar mountain range 

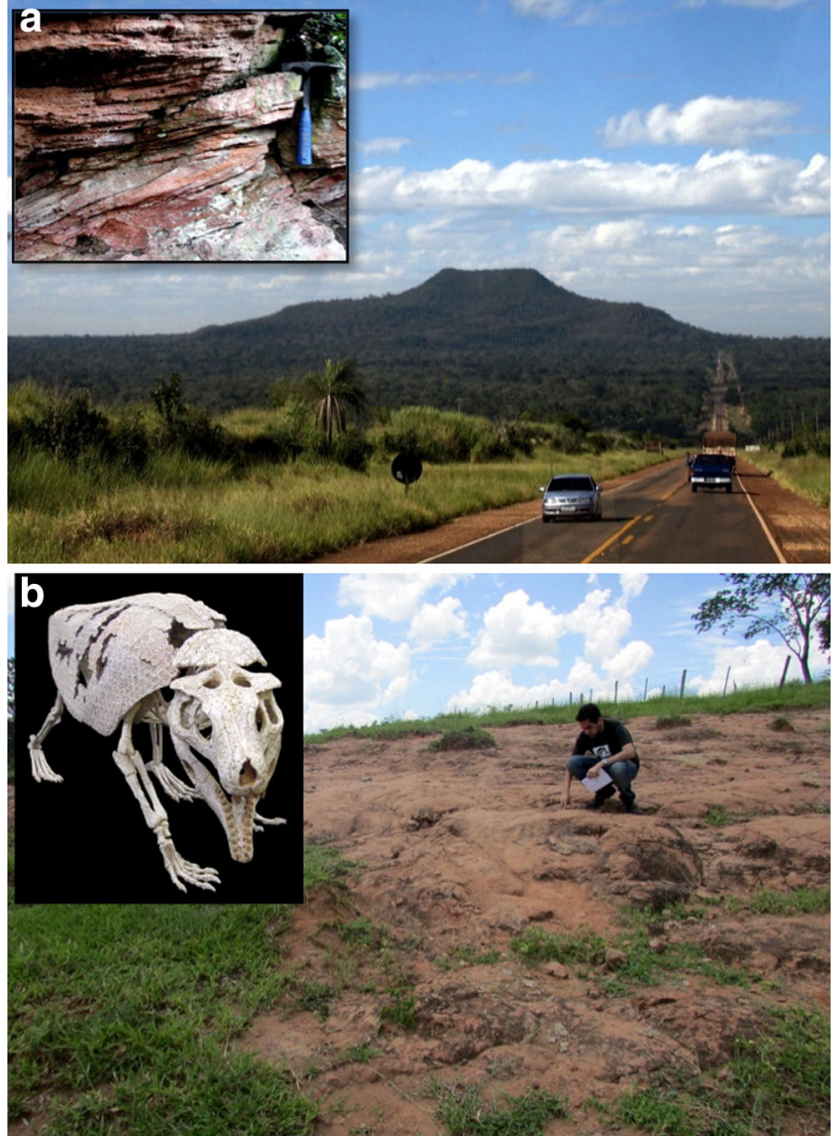

Fig. 9 Selected geosites of the geological framework 'Bauru Basin'. a Geosite 'Morro do Diabo' (Devil's Hill) at Teodoro Sampaio. The highest exposure in the state is a testimony hill formed by silicified sandstone deposits of dunes of the ancient desert Caiuá. It is associated with the evolution of the South American erosion surface $(\mathrm{K}-\mathrm{Pg})$. It is an expressive testimony of peculiar geological processes associated to the evolution of the topography in the last 90 million years. SV: 3.80 . b Geosite 'Fossil Reptiles from General Salgado'. One of the biggest fossil complexes in the Bauru Basin in São Paulo. About 20 skeletons of crocodyliformes, vertebrae of ophides (Anilioidea), fossil eggs, trace fossils of invertebrates and vertebrates coprolites were already identified. The photographs show the Fazenda São José (Buritis) site and in detail a reconstruction of the crocodilian Armadillosuchus arrudai (Marinho and Carvalho 2009; Carvalho et al. 2010). SV: 3.10

and concomitant subsidence in the Santos Basin (Almeida and Carneiro 1998). The second is related to climatic variations and sea-level fluctuations occurred during the Quaternary (Suguio and Martin 1978). Because of differential geotectonic processes, the São Paulo coast can be divided into three sectors: southern, northern and central coast. In the southern coast, the Serra do Mar mountain range is located far from the shoreline, then coastal plains are extensive and ocean beaches are straight and open. In the northern coast, Serra do Mar is closer to the shoreline; therefore, coastal plains and beaches are significantly reduced, and the presence of small bays is ordinary. In the central sector, physiographic characteristics are intermediate and controlled by the proximity of Serra do Mar to the
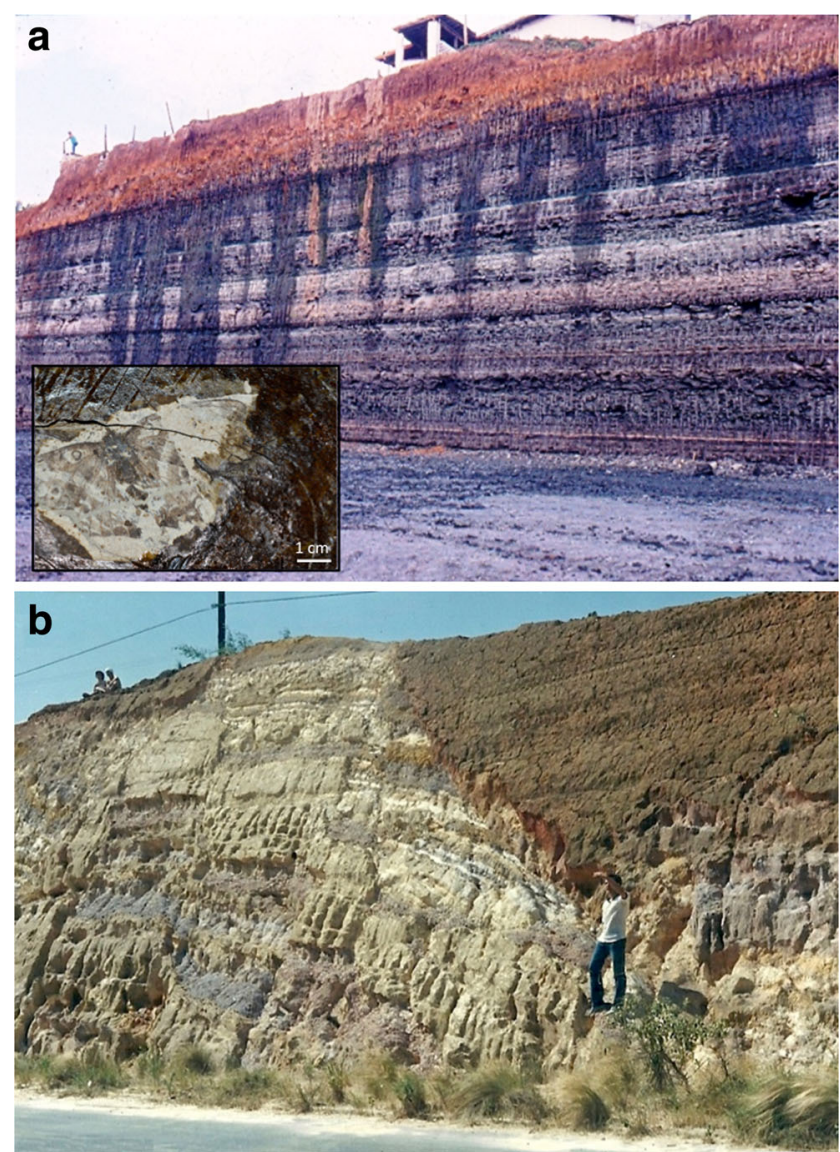

Fig. 10 Selected geosites of the geological framework 'Southeastern Continental Rift'. a Geosite 'Tremembé Palaeolake at the Santa Fé Mine'. The outcrop shows lacustrine green massive claystones and shales from the Tremembé Formation, Taubaté Basin. It constitutes the most important fossiliferous occurrence of the Brazilian Palaeogene. The detail inset shows a fossil of the butterfly Neorinella garciae. Photos: M. J. Garcia. SV: 4.00. b Geosite 'Normal faults of Taubaté'. Negative flower structure related to NNE-SSW-oriented post-sedimentary faults affecting Miocene fluvial-meandering deposits of the Pindamonhangaba Formation, Taubaté Basin. Horst structures can be also observed in the same road section. Photo: M. J. Garcia. SV: 3.30

shoreline. Because of this different physiographic behaviour, Pleistocene marine deposits are widely displayed at the southern coastal plains, but rare at the northern coastal plains, where Holocene deposits predominate. Representative geosites are shown in Fig. 11.

\section{Geomorphological Units and Landforms}

Coordinators are Marisa Fierz and Jurandyr Ross (University of São Paulo).

The general geological setting of the state of São Paulo is composed of two quite distinct domains: about $30 \%$ of the state area corresponds to Precambrian rocks of the crystalline basement, while about $70 \%$ is represented by sedimentary deposits. These natural differences control the 


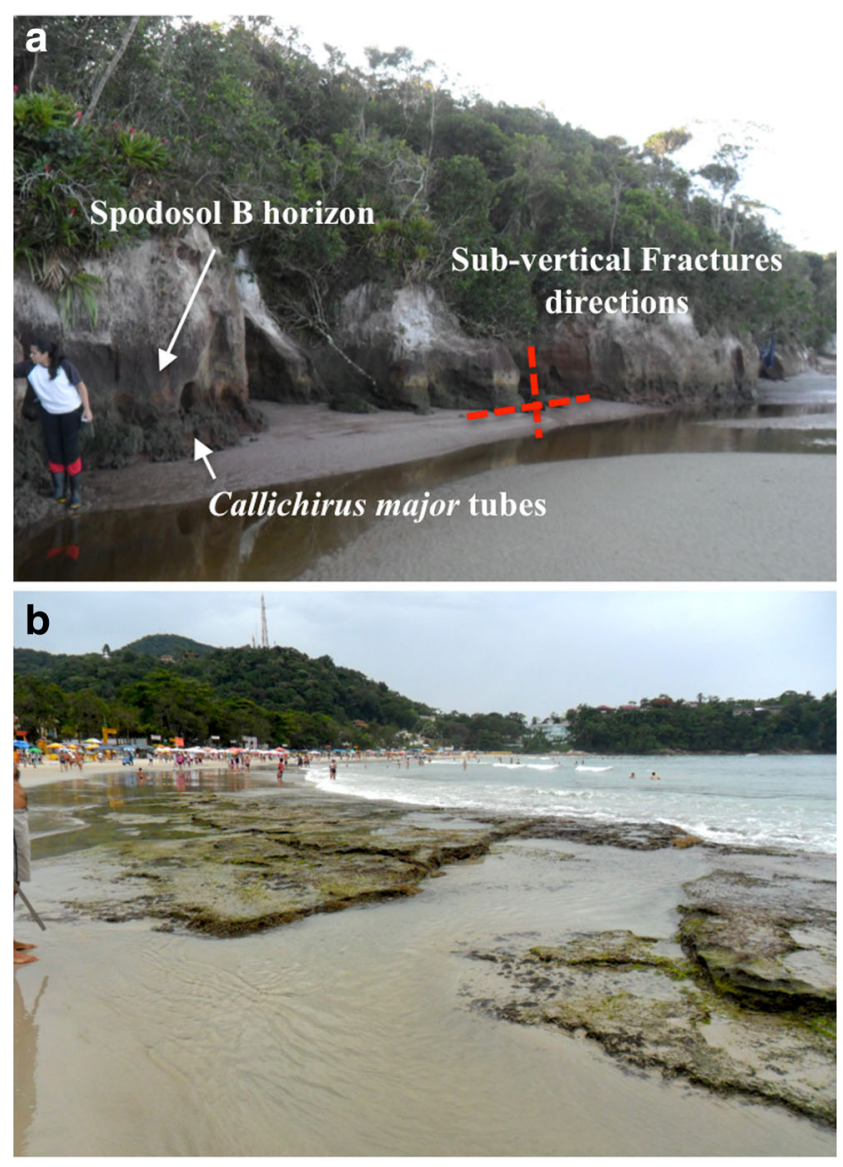

Fig. 11 Selected geosites of the geological framework 'Continental and coastal Neogenic and Quaternary evolution'. a Geosite 'Cliffs in Pleistocene Marine terraces' (Souza 2015). It is an outcrop of a Pleistocene marine terrace characterised by beach fine sands, and Callichirus major tubes concentrate at the base, both indicating deposition in the foreshore-upper shoreface zones, a system of orthogonal joints likely of tectonic origin, and a thick Spodosol B horizon (up to $14 \mathrm{~m}$ in deep) with structures indicative of polycyclic evolution which started in the Pleistocene. The origin of the cliff is probably related to the Holocene marine transgression which occurred in 5600 years cal BP. SV: 3.50. b Geosite 'Beachrock of Ubatuba' (Souza 2013). It is the only beachrock outcropping in the state of São Paulo coastal zone. It lays ca. $0.4 \mathrm{~m}$ below the current mean sea level, although the entire body keeps recovered by beach fine sands almost all the time. The body is composed of Holocene beach deposits formed between the backsore and the upper foreshore zone, which were cemented by carbonate precipitation in the intertidal zone (foreshore zone) during the middle Holocene (4610 years cal BP). The body was fractured by sub-vertical orthogonal joints (likely in tectonic origin) that had been filled with aeolian sediments, which were cemented around 3790 years cal BP. Sea-urchin holes are widely distributed on the beachrock surface, evidencing a rise in the sea level after the second phases of cementation. SV: 3.20

diversity of landforms, as well as the geomorphology of the area (Almeida 1964), originating two main domains: (i) the Atlantic Shield, with limited sedimentary deposits and Jurassic-Palaeocene intrusions and (ii) the Platform cover, represented by sedimentary and volcanic sequences of Paraná and Bauru basins, with significant JurassicCretaceous intrusions. This geomorphological subdivision of the state is defined in the Geomorphological Map of the State of São Paulo (Ross and Moroz 1997) where landforms are subdivided into macrocompartiments (morphostructures) and smaller compartments (morphoesculptures).

Three morphostructural units were defined as follows:

1. Atlantic Orogenic Belt, for which five major tectonic domains are described (Carneiro and Ponçano et al. 1981): Joinvile Massif, Apiaí Fold Belt, São Roque Fold Belt, Guaxupé Massif and Uruaçu Fold Belt

2. Paraná and Bauru basins, infilled from the Devonian/ Silurian to the Jurassic, which cover the western part of the state. After the Upper Jurassic, new tectonic processes occurred in both basins, originating new sedimentary sequences and basaltic rocks, which complete the package that makes up the platform cover.

3. Cenozoic sedimentary basins (São Paulo, Taubaté and Coastal) developed in restricted areas of the Atlantic Shield.

The identification of geosites for this geological framework has tried to follow the specific characteristics of these three morphostructural units. The selected geosites cover the main geological landforms of the state, which highlight the importance of geomorphology in the interpretation of the recent geological history of the state of São Paulo. Representative geosites are shown in Fig. 12.

\section{Caves and Karst Systems}

Coordinator is William Sallun Filho (Geological Institute, State of São Paulo).

Caves and karst represent unique landscapes with important geological, biological and cultural role. The karst areas in Brazil occupy a small portion of the territory and are usually located in sparsely populated areas. However, some of them have great economic interest, as a source of minerals and water, and are very vulnerable to pollution and geological risks. Even with recognised geological, palaeoclimatic and palaeontological importance, karst and caves have few studies in Brazil.

The cave environments host a wide variety of fauna, being of great importance in evolutionary studies because of the high adaptation of the animals to the cave environment. The caves also are home to numerous archaeological and palaeontological sites of great cultural and scientific importance. Today, they play an important social, cultural and religious role throughout Brazil.

According to the Brazilian Speleological Society (SBE), 720 caves are registered in the São Paulo state. The carbonate area is very small, about $1.5 \%$ of the whole state, mostly located in the region of the Ribeira de Iguape River Valley, 

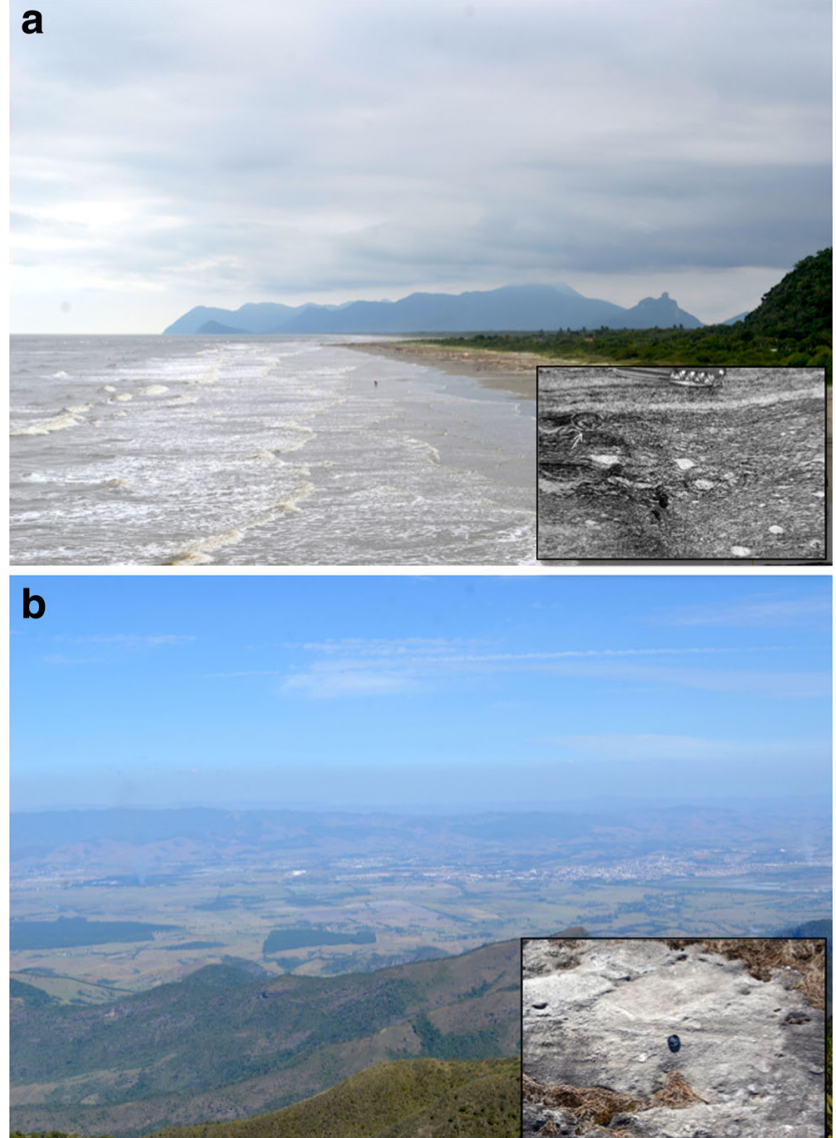

Fig. 12 Selected geosites of the geological framework 'Geomorphological units and geoforms'. a Geosite 'Jureia's Massif'. It is a granitic/gneiss relief in the middle of the coastal plain, which may represent an ancient island that was incorporated into the continent by marine depositional processes. Geologically, it is part of the Registro Domain and mostly composed of migmatitic granite gneiss rocks, representing a Palaeoproterozoic terrane (1.9-2.2 Ga) strongly deformed during the Neoproterozoic (750-580 Ma). In the detail mylonitic foliation in paragneiss, defined by quartzo-feldspatic bands and orientation and stretching of centimetre-sized feldspar and garnet porphyroclasts (arrow) - Passarelli et al. (2007). SV: 4.00. b Geosite 'Itapeva Peak'. This important geomorphological feature is located at the Campos do Jordão Plateau, one of the highest blocks of crystalline massifs of Southeastern Brasil. Geologically, it is composed of Neoproterozoic-Cambrian metassedimentary rocks from the Itapeva Formation, related to a strike-slip basin. The photograph shows a view from the peak with the Paraíba River Valley, along the Continental Rift of Southeastern Brazil and the Serra do Mar in the background. In the detail metaconglomeratic sandstone from the Pico de Itapeva Formation. SV: 3.80

in narrow bands of metamorphic Proterozoic carbonate rocks of the Açungui Group. The geological conformation of the carbonate rocks, the youngest tectonic process and the humid subtropical climate shape the entrenched landforms and the karst terrains with scarps, dolines, sinks, resurgences, polygonal karst (Karmann 1994; Karmann and Sanchez 1986). The cave morphology is mainly composed by sink-resurgence systems, forming river caves, with high depths, and common vadose shafts. Among many caves are highlighted the
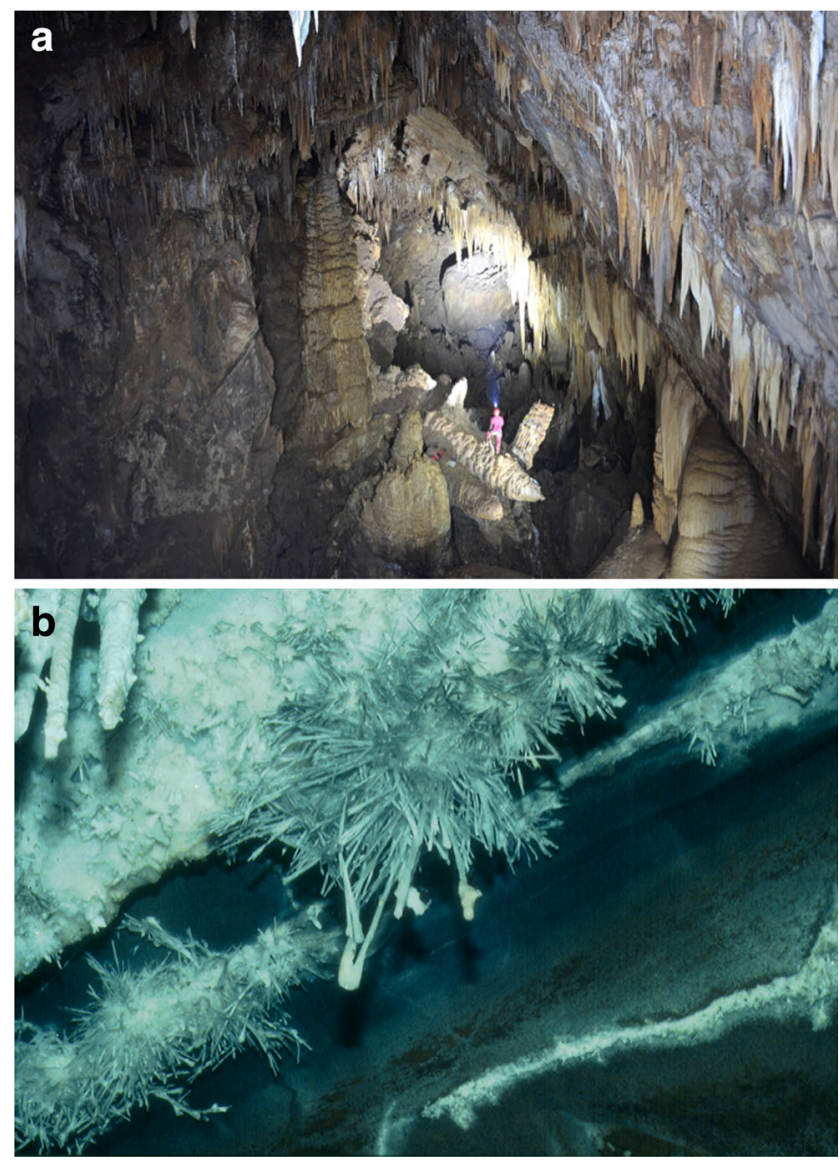

Fig. 13 Selected geosites of the geological framework 'Caves and Karst Systems'. a Geosite 'Tapagem Cave', also known as 'Devil's Cave', Eldorado. It is one of the most famous and most visited show caves in Brazil, developed in an isolated body of dolomite marble karst from Serra do André Lopes, in the Ribeira River Valley (south of the State of São Paulo). The picture shows a large collapse room with fallen stalagmites (the 'Fallen Giants Room') (Sallun Filho et al. 2015). SV: 4.00. b Geosite 'Santana Cave', Iporanga. It is a show cave, considered by many cavers one of the best Brazilian cave in terms of speleothems, it is developed in the impure and metamorphic-banded limestones of the Lageado Formation of the Açungui Group. Important speleothems include rimstone dams, moonmilk, helictites and anthodites (aragonite flowers), among others (Labegalini and Auler 1997). SV: 3.70

'Tapagem Cave' (also known as 'Devil's Cave') and 'Santana Cave' by the dimensions, abundance of speleothems (Labegalini and Auler 1997; Sallun Filho et al. 2015) and importance of palaeoclimatic records (Cruz et al. 2005). These two caves and others in the Ribeira do Iguape River Valley were few of the first caves described in the literature in Brazil by Krone $(1898,1909)$, who emphasised their scientific relevance and need for conservation.

Pseudokarst caves in granite/gneiss are $8 \%$ of the known caves of the state, mostly distributed in the crystalline basement, made up of old Archaean to Proterozoic igneous and metamorphic rocks. Other non-carbonate caves occur in siliciclastic rocks, with $7 \%$ of the known caves mainly located in the Mesozoic sandstones of the Paraná Basin. At least, there 
is only one cave developed in Quaternary limestone tufa. Representative geosites are shown in Fig. 13.

\section{Final Considerations}

The main result of this inventory is expressed by 142 geosites representing 11 geological frameworks that were defined taking into consideration the present geological and geomorphological knowledge of the state of São Paulo. One main characteristic of such inventories is that they are not finished products because geological knowledge is always advancing. In order to allow the possibility for a constant updating, an online database of the geological heritage of São Paulo is under construction, which will be available to the scientific community. The update of the scientific data of geosites already in the inventory and the proposition of new geosites will be both possible. New proposals of geosites will be reviewed by the scientific coordinator of the corresponding geological framework so as to decide on its eventual approval. In order to guarantee the coherence of all geosites in the database, new geosites must meet the same selection and assessment criteria that were applied to all other geosites.

The scientific value and risk of degradation were assessed for all inventoried geosites.

Geoheritage inventories are supposed to work as factual foundations for any decision on conservation. The results of this assessment will therefore be used for the establishment of management priorities within the state. However, the management of geosites is no longer a task for the geoscientific community. Considering the legal framework of the São Paulo state, the responsibility for the definition and implementation of nature conservation policies is under the Environment Secretary of the State Government. Taking this setting into consideration, the geoheritage inventory was supplied to the Geological Institute, the state agency under the Environment Secretary. The geoscientific community expects that the state administration will use this information to develop a state geoconservation strategy, starting with the management of the geosites with higher scientific value and risk of degradation.

This geoheritage inventory was a pioneering initiative in Brazil and Latin America. For the very first time, a systematic geosite inventory, using a specific method with clear criteria and focused on a pre-defined aim, was carried out by the geoscientific community in a large territory. It is expected that this inventory will be used as a model to be applied in other Brazilian states and other countries of Latin America.

Acknowledgements The authors acknowledge the Science Without Borders Programme, Process 075/2012, which supported this study and the São Paulo Research Foundation (FAPESP), Process 2011/17261-6. We also thanks C. Mazoca for his help with maps and figures.

\section{References}

Almeida FFM (1964) Os fundamentos geológicos do relevo paulista. Boletim do Instituto Geográfico e Geológico 41:169-263

Almeida FFM (1986) Distribuição regional e relações tectônicas do magmatismo pós-Paleozóico no Brasil. Revista Brasileira de Geociências 16:325-349

Almeida FFM, Carneiro CDR (1998) Origem e evolução da Serra do Mar. Revista Brasileira de Geociências 28(2):135-150

Almeida FFM, Hasui Y, Brito Neves BB, Fuck RA (1981) Brazilian structural provinces: an introduction. Earth-Sci Rev 17:1-29

Almeida FFM, Brito Neves BB, Carneiro CDR (2000) The origin and evolution of the South American platform. Earth-Sci Rev 50:77-111

Araújo CC (1999) Aplicação de Geoprocessamento na análise de favorabilidade para mineralizações de chumbo, zinco e cobre nas Folhas Cerro Azul e Apiaí, Vale do Ribeira, (SP e PR). Master's Dissertation, Instituto de Geociências, Universidade de São Paulo, São Paulo, Brasil

Atencio D, Hypolito R (1994) Fosfatos e silicatos secundários de urânio de perus, São Paulo. Rev Bras Geosci 24(1):43-51

Azevedo DT (1994) Os turmalina granitos de Perus-SP: aspectos geológicos e petrográficos. Master's Dissertation, Instituto de Geociências, Universidade de São Paulo, São Paulo, Brasil

Azevedo Sobrinho JM, Janasi VA, Simonetti A, Heaman LM, Santoro J, Diniz HN (2011) The Ilha Anchieta quartz Monzonite: the southernmost expression of ca. 500 Ma post-collisional magmatism in the Ribeira Belt. An Acad Bras Cienc 83(3):891-906. doi:10.1590 /S0001-37652011000300010

Beljavskis P, Juliani C, Garda GM, Bettencourt JS, Xavier RP (1999) Overview of the gold mineralisation in the metavolcanicsedimentary sequence of the Serra do Itaberaba Group, São Paulo, Brazil. In: Standley C.J. et al. Mineral Deposits: Processes to Processing 1. Balkema 151-153.

Beljavskis P, Garda GM, Juliani C, Silva D (2003) The occurrence of intermediate schorl-dravite and alkali-deficient, $\mathrm{Cr}-(\mathrm{V})$ bearing tourmalines in the Serra do Itaberaba group volcanic-sedimentary sequence (São Paulo- Brazil). An Acad Bras Cienc 75(2):209-234

Beljavskis P, Garda GM, Mansueto M, Silva D (2005) Os Turmalinitos vulcanogênicos da Formação Morro da Pedra Preta, Grupo Serra do Itaberaba (SP): petrografia, composição química da turmalina e implicações metalogenéticas. Geologia USP, Série Científica 5(1): $1-18$

Brilha J (2016) Inventory and quantitative assessment of geosites and geodiversity sites: a review. Geoheritage 8(2):119-134

Brilha $\mathrm{J}$ et al. (2010) O inventário nacional do património geológico: abordagem metodológica e resultados. e-Terra 18(1)

Campanha GAC (2002) O papel do Sistema de Zonas de Cisalhamento Transcorrentes na configuração da porção meridional da Faixa Ribeira. Thesis, Instituto de Geociências, Universidade de São Paulo, São Paulo, Brasil

Campanha GAC, Ens HH, Poçano WL (1994) Análise morfotectônica do Planalto do Juqueriquerê, São Sebastião. Revista de Geociências 24: $32-42$

Campos Neto MC (2000) Orogenic systems from southwestern Gondwana: an approach to Brasiliano-Pan African cycle and collage in southeastern Brazil. In: Cordani UG, Milani EJ, Thomaz Filho A, Campos DA (ed.) Tectonic evolution of South America. Rio de Janeiro, p. 335-365

Carneiro CDR (2000) The historical Jaraguá gold excavations. In: Schobbenhaus C, Campos DA, Queiroz ET, Winge M, BerbertBorn M (eds) Sítios Geológicos e Paleontológicos do Brasil. http://sigep.cprm.gov.br/sitio098/sitio098.pdf

Carneiro CDR, Ponçano WL (1981) As unidades geológicas do estado de São Paulo. In: Almeida FFM, Hasui Y, Ponçano WL, Dantas ASL, Carneiro CDR, Melo MS, Bistrichi CA (eds) Mapa Geológico do 
Estado de São Paulo - Nota Explicativa. IPT - Instituto de Pesquisas Tecnológicas do estado de São Paulo, São Paulo, pp 4-11

Carneiro CDR, Santos LF, Silva JRB (2011) Cavas históricas de ouro do Jaraguá: o que resta para se preservar? Brazilian Journal of Geology 41(1):108-119

Carvalho IS, Vasconcellos FM, Marinho TS, Nobre PH, Campos ACA, Arruda JTA (2010) Répteis Fósseis de General Salgado, SP Registro de transformações ambientais na Bacia Bauru durante o Cretáceo. In: Winge M, Schobbenhaus C, Souza CRG, Fernandes ACS, Berbert-Born M, Sallun Filho W, Queiroz ET (ed.) Sítios Geológicos e Paleontológicos do Brasil.

Christiano-De-Souza IC, Ricardi-Branco FS (2015) Study of the West Gondwana Floras during the Late Paleozoic: a paleogeographic approach in the Paraná Basin, Brazil. Palaeogeogr Palaeoclimatol Palaeoecol 426:159-169

Coutinho JMV (1980) Carta geológica da região metropolitana da Grande São Paulo 1:100.000. Emplasa.

Cruz FW Jr, Karmann I, Viana O, Burns SJ, Ferrari JA, Vuille M, Sial AN, Moreira MZ (2005) Stable isotope study of cave percolation waters in subtropical Brazil: implications for paleoclimate inferences from speleothems. Chem Geol 220(3-4):245-262. doi:10.1016/j.chemgeo.2005.04.001

Deckart K, Féraud G, Marques LS, Bertrand H (1998) New time constraints on dykes swarms related to the Paraná-Etendeka magmetic province, and subsequent South Atlantic opening, southeastern Brazil. J Volcanol Geotherm Res 80:67-83

Elliot-Meadows SR, Appleyard EC (1991) The alteration geochemistry and petrology of the Lar Ct-Zn deposit, Lynn Lake area, Manitoba, Canada. Econ Geol 86:486-505

Faleiros FM, Campanha GAC, Martins L, Vlach SRF, Vasconcelos PM (2011) Ediacaran high-pressure collision metamorphism and tectonics of the southern Ribeira belt (SE Brazil): evidence for terrane accretion and dispersion during Gondwana assembly. Precambrian Res 189(3-4):263-291

Faleiros AM, Campanha GAC, Faleiros FM, Bello RMS (2014) Fluid regimes, fault-valve behaviour and formation of gold-quartz veinsthe Morro do Ouro Mine, Ribeira Belt, Brazil. Ore Geol Rev 56: 442-456

Fernandes FL (1993) Arcabouço estrutural e evolução da Bacia de Taubaté-SP. Master Thesis, Universidade Federal de Ouro Preto, Brasil

Fernandes LA (2006) Caiuá Desert sedimentary environments and facies (Caiuá Group, Late Cretaceous, Brazil). In: Congreso Latinoamericano de Sedimentología 4. Resúmes. p. 97

Fernandes FL, Chang HK (2001) Modelagem gravimétrica da Bacia de Taubaté-Vale do Rio Paraíba do Sul, leste do Estado de São Paulo. Revista Brasileira de Geofísica 19:131-144

Fernandes LA, Coimbra AM (1996) A Bacia Bauru (Cretáceo Superior, Brasil). An Acad Bras Cienc 68(2):195-205

Fernandes LA, Coimbra AM (2000) Revisão estratigráfica da parte oriental da Bacia Bauru (Neocretáceo). Brazilian Journal of Geology 30(4):723-734

Fernandes LA, Magalhães Ribeiro CM (2015) Evolution and palaeoenvironment of the Bauru Basin (Upper Cretaceous, Brazil). J S Am Earth Sci 61:71-90

Garcia MGM (2012) Gondwana geodiversity and geological heritage: examples from the north coast of São Paulo State, Brazil. Anuário do Instituto de Geociências (Online) 35:101-111

García-Cortéz A, Carcavilla Urquí L (2009) Documento metodológico para la elaboración del inventario español de lugares de interés geológico (IELIG). Instituto Geológico y Minero de España, Madrid version 12, $61 \mathrm{pp}$

Garda GM, Beljavskis P, Juliani C, Boyce AJ (2002) Sulfur stable isotope signatures of the Morro da Pedra Preta Formation, Serra do Itaberaba Group, São Paulo State, Brazil. Geochim Bras 16:79-97
Garda GM, Beljavskis P, Juliani C, Silva D (2003) Geochemistry of tourmalines associated with iron formation and quartz veins of the Morro da Pedra Preta Formation, Serra do Itaberaba Group (São Paulo, Brazil). An Acad Bras Cienc 75(2):209-234

Garda GM, Beljavskis P, Mansueto M (2005) Rochas ricas em turmalina da Formação Morro da Pedra Preta: relações com os turmalinitos portadores de ouro do Grupo Serra do Itaberaba, SP. Geologia USP, Série Científica 5(2):33-48

Garda GM, Trumbull RB, Beljavskis P, Wiedenbeck M (2009) Boron isotope composition of tourmalinite and vein tourmalines associated with gold mineralisation, Serra do Itaberaba Group, central Ribeira Belt, SE Brazil. Chem Geol 264(1-4):207-220

Gurgueira MG (2013) Correlação de dados geológicos e geotécnicos na Bacia de São Paulo. Master's Dissertation, Instituto de Geociências, Universidade de São Paulo, São Paulo, Brasil

Hasui Y, Ponçano WL (1978) Geossuturas e Sismicidade no Brasil. Congresso Brasileiro de Geologia de Engenharia, São Paulo. Anais 1:331-338

Heilbron M, Pedrosa-Soares AC, Campos Neto MC, Silva LC, Trouw RAJ, Janasi VA (2004) Província Mantiqueira. In: Mantesso-Neto V, Bartorelli A, Carneiro CDR, Brito Neves BB (org.) Geologia do Continente Sul-Americano - Evolução da Obra de Fernando Flávio Marques de Almeida. Ed Beca:203-234

IBGE (2016) Brazilian Institute of Geography and Statistics. http://censo2010.ibge.gov.br. Accessed in March 15th

Janasi VA, Ulbrich HHGJ (1992) Inventário bibliográfico de granitos do Estado de São Paulo. Boletim IG-USP. Publicação Especial 11:1253

Juliani C (1993) Geologia, petrogênese e aspectos metalogênicos dos grupos Serra do Itaberaba e São Roque na região das serras do Itaberaba e da Pedra Branca, NE da cidade de São Paulo, SP. PhD Thesis, Instituto de Geociências, Universidade de São Paulo, São Paulo, Brasil

Juliani C, Schorscher HD, Pérez-Aguilar A (1994) Corundum-margarite schists ("marundites") in the Precambrian Serra do Itaberaba Group, São Paulo, Brazil: geological relationships and petrogenesis. Anais da Academia Brasileira de Ciências, Rio de Janeiro 66:498

Juliani C, Hackspacher PC, Dantas EL, Fetter AH (2000) The Mesoproterozoic volcano-sedimentary Serra do Itaberaba Group of the Central Ribeira Belt, São Paulo, Brazil: implications for the age of overlying São Roque Group. Brazilian Journal of Geology 30: $82-86$

Karmann I (1994) Evolução e dinâmica atual do sistema cárstico do alto Vale do Rio Ribeira de Iguape, sudeste do Estado de São Paulo. PhD Thesis, Instituto de Geociências, Universidade de São Paulo, São Paulo, Brasil

Karmann I, Sanchez LE (1986) Speleological Provinces in Brazil. In: Congreso Internacional de Espeleologia, 9. Anais.... Barcelona: IUS. v.1, p. 151-153

Krone R (1898) As grutas calcareas de Iporanga. Revista do Museu Paulista 3:477-500

Krone R (1909) Estudo sobre as cavernas do Valle do Rio Ribeira. Arquivos do Museu Nacional 15:139-166

Labegalini JA, Auler AS (1997) Caverna Santana, Brazil. In: Carol A. Hill; Paolo Forti. (Org.). Cave minerals of the world. Huntsville: National Speleological Society 1:340-342

Lima FF, Brilha JB, Salamuni E (2010) Inventorying geological heritage in large territories: a methodological proposal applied to Brazil. Geoheritage 2(3-4):91-99

Limarino CO, Césari SN, Spalletti LA, Taboada AC, Isbell JLI, Geuna S, Gulbranson E (2014) A paleoclimatic review of southern South America during the late Paleozoic: a record from icehouse to extreme greenhouse conditions. Gondwana Res 25:1396-1421

Linol B, De Wit MJ, Milani J, Guillocheau F, Scherer C (2015) New regional correlations between the Congo, Parana' and Cape-Karoo basins of Southwest Gondwana. In: de Wit MJ et al (eds) Geology 
and resource potential of the Congo Basin, regional geology reviews. Springer, Berlin Heidelberg. doi:10.1007/978-3-642-29482213

Marinho TS, Carvalho IS (2009) An armadillo-like sphagesaurid crocodyliform from the Late Cretaceous of Brazil. J S Am Earth Sci 27:36-41

Martin MA; Juliani C; Clarimundo SJ (1998) Metavulcanoclásticas básicas e mineralizações auríferas associadas à zona de cisalhamento: formação Morro Da Pedra Preta, Grupo Serra do Itaberaba a NW de São Paulo, SP. In: Congresso Brasileira de Geologia, 40. Belo Horizonte, SBG, Anais....,p. 147

Milani EJ, Melo JHG, Souza PA, Fernandes LA, França AB (2007) Bacia do Paraná. Boletim de Geociências da Petrobras 15(2):265-287

Mora CAS, Campanha GAC, Wemmer K (2013) Microstructures and K$\mathrm{Ar}$ illite fine-fraction ages of the cataclastic rocks associated to the Camburu Shear Zone, Ribeira Belt, Southeastern Brazil. Brazilian Journal of Geology 43(4):607-622

Paiva IP, Morgental A (1980) Prospecto Ouro nas Regiões Auríferas dos Agudos Grandes e Morro do Ouro, Vale do Ribeira. CPRM/SUREG, São Paulo 63p. (Relatório)

Passarelli CR, Basei MAS, Prazeres-Filho HJ, Siga O Jr, Szabó GAJ, Marco-Neto J (2007) Structural and geochronological constraints on the evolution of the Juréia Massif, Registro Domain, State of São Paulo, Brazil. An Acad Bras Cienc 79(3):441-455

Pérez-Aguilar A, Juliani C, Martin MAB (2000) Mesoproterozoic paleohydrothermalsystem in the Morro da Pedra Preta Formation, Serra do Itaberaba Group, São Paulo State, Brazil. Revista Brasileira de Geociências 30:413-416

Pérez-Aguilar A, Juliani C, Monteiro LVS, Fallick AE, Bettencourt JS (2005) Stable isotopic constrains on Kuroko-type paleo-hydrothermal systems in the Mesoproterozoic Serra do Itaberaba Group, São Paulo State, Brazil. J S Am Earth Sci 18:305-321

Pérez-Aguilar A, Juliani C, Monteiro LVS (2007) Petrografia de zonas de alteração hidrotermal mesoproterozóicas do tipo Kuroko no Grup Serra do Itaberaba (SP) e seu uso na exploração mineral. Revista do Instituto Geológico 27-28(1/2):31-52

Pérez-Aguilar A, Juliani C, Monteiro LVS, Bettencourt JS, Fallick AE, Barros EJ, Andrade MR, Oliveira AM (2011) Mineralização highsulfidation submarina mesoproterozóica no Grupo Serra do Itaberaba, SP: implicações metalogenéticas em cinturões metamórficos. In: Franz JC, Marques JC, Jost H (eds) Contribuições à metalogenia do Brasil. UFRGS, Porto Alegre

Pérez-Aguilar A, Barros EJ, Andrade MRM, Oliveira ES, Juliani C, Oliveira MAS (2012a) Geoparque Ciclo do Ouro, Guarulhos, SP. In: Schobbenhaus C, Silva CR (eds) Geoparques do BrasilPropostas. Brasília, CPRM, pp 541-582

Pérez-Aguilar A, Juliani C, Andrade MRM, Barros EJ (2012b) Reconstituição do sistema de transporte de água associado à lavra de ouro durante o período colonial nos arredores de guarulhos, SP, Brasil. Revista do Instituto Geológico 33(1):1-22

Pérez-Aguilar A, Juliani C, Barros EJ, Andrade MRM, Braga DA, Santos RO (2013) Archaeological gold mining structures from colonial period present in Guarulhos and Mairiporã, São Paulo State, Brazil. Geoheritage 5(2):87-105

Pérez-Aguilar A, Moreira IV, Silles JS, Juliani C, Carvalho FMS (2014) Produtos metamórficos de sistemas high-sulfidation oceânicos mesoproterozóicos, Grupo Serra do Itaberaba, SP. Revista do Instituto Geológico 35(1):1-17

Perrotta MM, Salvador ED, Lopes RC, D'Agostinho LZ, Peruffo N, Gomes SD, Sachs LLB, Meira VT, Garcia MGM, Lacerda Filho JV (2005) Mapa geológico do estado de São Paulo, escala 1: 750.000. Programa levantamentos geológicos básicos do Brasil, CPRM, São Paulo

Raposo MIB, Ernesto M, Renne PR (1998) Paleomagnetism and 40Ar/ 39Ar dating of the Early Cretaceous Florianópolis dike swarm
(Santa Catarina Island), Southern Brazil. Phys Earth Planet Inter 108:275-290

Renne PR, Deckar K, Ernesto M, Féraud G, Piccirillo EM (1996) Age of Ponta Grossa swarm (Brazil), and implications to Paraná flood volcanism. Earth Planet Sci Lett 144:199-211

Ribeiro RR, Christofoletti SR, Batezelli A, Fittipaldi FA, Zanchetta D (2013) Inventário e avaliação do patrimônio natural geológico da região de Rio Claro (SP). Revista do Instituto Geológico 34(1):1-27

Ricardi-Branco F, Caires E, Silva AM (2006) Gigant Stromatolites field of Santa Rosa de Viterbo, State of São Paulo. Excellent record of the Irati Permian sea coastal environment, Paraná Basin. In: Winge M, Schobbenhaus C, Berbert-Born M, Queiroz ET, Campos DA, Souza CRG, Fernandes ACS (org.). Sítios geológicos e paleontológicos do Brasil Vol. II: $1-9$

Riccomini C (1989) O Rift Continental do Sudeste do Brasil. São Paulo. $\mathrm{PhD}$ Thesis, Instituto de Geociências, Universidade de São Paulo, Brasil

Riccomini C, Sant'anna LG, Ferrari AL (2004) Evolução geológica do rift continental do sudeste do Brasil. In: Mantesso-Neto V, Bartorelli A, Carneiro CDR, Brito Neves BB (org.) Geologia do Continente Sul-Americano - Evolução da Obra de Fernando Flávio Marques de Almeida, Ed Beca, cap. 23

Rocha-Campos AC (2002) Varvito de Itu, SP. Registro clássico da glaciação neopaleozóica. In: Schobbenhaus C, Campos DA, Queiroz ET, Winge M, Berbert-Born M (eds) Sítios Geológicos e Paleontológicos do Brasil. DNPM / CPRM / SIGEP I, Brasília, pp $147-154$

Rohn R (2007) The Passa Dois Group (Paraná Basin, Permian): investigations in progress. In: I Workshop-Problems in the Western Gondwana Geology, South America - Africa correlations: du Toit revisited. Gramado. Extended Abstracts. 1:151-157

Ross JLS, Moroz IC (1997) Mapa Geomorfológico do Estado de São Paulo. IPT/FAPESP, São Paulo 63p

Sallun Filho W, Cordeiro BM, Karmann I (2015) Structural and hydrological controls on the development of a river cave in marble (Tapagem Cave, SE Brazil). Int J Speleol 44(1):75-90

Santos PR, Rocha-Campos AC, Canuto JR (1996) Patterns of late Paleozoic deglaciation in the Paraná Basin, Brazil. Palaeogeogr Palaeoclimatol Palaeoecol 125:165-184

Souza CRG (2013) The Ubatuba beachrock (state of São Paulo, Brazil): a new evidence of a mid-Holocene negative sea-level. In: Abstracts 8th IAG Congress, Paris, 26-30

Souza CRG (2015) The Bertioga Coastal Plain: an example of morphotectonic evolution. In: B.C. Vieira, A.A.R. Salgado and L.J.C. Santos (eds.). Landscapes and landforms of Brazil, Chapter 11, p. 115-134. World Geomorphological Landscapes, DOI 10.1007/978-94-017-8023-0. OSpringer Science+Business Media Dordrecht. Book ISBN: 978-94-017-8022-3

Souza CRG, Hiruma ST, Sallun AEM, Ribeiro RR, Azevedo Sobrinho JM (eds) (2008) "Restinga": conceitos e empregos do termo no Brasil e implicações na legislação ambiental. Secretaria do Meio Ambiente, Instituto Geológico, São Paulo

Suguio K, Martin L (1978) Quaternary marine formations of the states of São Paulo and Southern Rio de Janeiro. In: International Symposium on Coastal Evolution in the Quaternary, São Paulo, v. $1,55 \mathrm{p}$

Turner S, Regelous M, Kelly S, Hawkesworth C, Mantovani MSM (1994) Magmatism and continental break-up in the South Atlantic: high precision 40Ar/39Ar geochronology. Earth Planet Sci Lett 121: 333-348

Weber W, Siga Júnior O, Sato K, Reis Neto JM, Basei MAS, Nutman AP (2004) A Formação Água Clara na Região de Araçaíba - SP: Registro U-Pb de Uma Bacia Mesoproterozóica. Geologia USP, Série Científica 4(1):101-104

Wimbledon WAP (1996) Geosites - a new IUGS initiative. Episodes 19: $87-88$ 
Wimbledon WA (2011) Geosites - a mechanism for protection, integrating national and international valuation of heritage sites. Geologia dell'Ambiente, supplemento n. 2/2011:13-25.

Wimbledon WA, Smith-Meyer S (eds) (2012) Geoheritage in Europe and its conservation. ProGEO, Oslo
Zalan PV, Oliveira JAB (2005) Origem e evolução estrutural do sistema de riftes cenozóicos do Sudeste do Brasil. Boletim de Geociências da Petrobras 13:269-300 